\title{
Fused Systems Based on 2-Aminopyrimidines: Synthesis Combining Deprotolithiation-in situ Zincation with N -Arylation Reactions and Biological Properties
}

\author{
Madani Hedidi, Julien Maillard, William Erb, Frédéric Lassagne, Yury \\ Halauko, Oleg Ivashkevich, Vadim Matulis, Thierry Roisnel, Vincent Dorcet, \\ Monzer Hamze, et al.
}

\section{To cite this version:}

Madani Hedidi, Julien Maillard, William Erb, Frédéric Lassagne, Yury Halauko, et al.. Fused Systems Based on 2-Aminopyrimidines: Synthesis Combining Deprotolithiation-in situ Zincation with N Arylation Reactions and Biological Properties. European Journal of Organic Chemistry, Wiley-VCH Verlag, 2017, 2017 (39), pp.5903-5915. 10.1002/ejoc.201701004 . hal-01624382

HAL Id: hal-01624382

https://hal-univ-rennes1.archives-ouvertes.fr/hal-01624382

Submitted on 26 Oct 2017

HAL is a multi-disciplinary open access archive for the deposit and dissemination of scientific research documents, whether they are published or not. The documents may come from teaching and research institutions in France or abroad, or from public or private research centers.
L'archive ouverte pluridisciplinaire HAL, est destinée au dépôt et à la diffusion de documents scientifiques de niveau recherche, publiés ou non, émanant des établissements d'enseignement et de recherche français ou étrangers, des laboratoires publics ou privés. 


\title{
Fused systems based on 2-aminopyrimidines: synthesis combining deprotolithiation-in situ zincation with $\mathrm{N}$-arylation reactions and biological properties
}

\author{
Madani Hedidi, ${ }^{[a, b, c]}$ Julien Maillard, ${ }^{[a]}$ William Erb, ${ }^{[a]}$ Frédéric Lassagne, ${ }^{[a]}$ Yury S. Halauko, ${ }^{[\mathrm{d}]}$ \\ Oleg A. Ivashkevich, ${ }^{[\mathrm{d}]}$ Vadim E. Matulis, ${ }^{[\mathrm{e]}}$ Thierry Roisnel, ${ }^{[\mathrm{ff}}$ Vincent Dorcet, ${ }^{[\mathrm{f]}]}$ Monzer Hamzée, ${ }^{[\mathrm{g}]}$ \\ Ziad Fajloun, ${ }^{*[\mathrm{~h}]}$ Blandine Baratte ${ }^{[i]}$ Sandrine Ruchaud, ${ }^{[i]}$ Stéphane Bach, ${ }^{*[]}$ \\ Ghenia Bentabed-Ababsa ${ }^{*[b]}$ and Florence Mongin ${ }^{*[a]}$
}

[a] Dr. M. Hedidi, J. Maillard, Dr. W. Erb, F. Lassagne, Prof. F. Mongin Equipe Chimie Organique et Interfaces Institut des Sciences Chimiques de Rennes UMR 6226 CNRS - Université de Rennes 1

Bâtiment 10A, Case 1003, Campus Scientifique de Beaulieu 35042 Rennes, France

E-mail: florence.mongin@univ-rennes1.fr https://iscr.univ-rennes1.fr/corint/bimetallic-synergy

[b] Dr. M. Hedidi, Prof. G. Bentabed-Ababsa Laboratoire de Synthèse Organique Appliquée Faculté des Sciences Exactes et Appliquées Université d'Oran 1 Ahmed Ben Bella, BP 1524 El M'Naouer 31000 Oran, Algeria

E-mail: badri_sofi@yahoo.fr

[c] Dr. M. Hedidi

Département chimie, Faculté des Sciences Exactes et Informatique Université Hassiba Benbouali de Chlef, Hay Es-salam RN 19 02000 Chlef, Algeria (present address)

[d] Dr. Y. S. Halauko, Prof. O. A. Ivashkevich

UNESCO Chair of Belarusian State University

14 Leningradskaya Str.

Minsk 220030, Belarus

E-mail: hys@tut.by

[e] Dr. V. E. Matulis

Research Institute for Physico-Chemical Problems of Belarusian State University

14 Leningradskaya Str.

Minsk 220030, Belarus

[f] Dr. T. Roisnel, Dr. Vincent Dorcet

Centre de Diffractométrie $X$

Institut des Sciences Chimiques de Rennes

UMR 6226 CNRS - Université de Rennes 1

Bâtiment 10B, Campus de Beaulieu

35042 Rennes, France

[g] Dr. M. Hamzé

Laboratoire Microbiologie, Santé et Environnement (LMSE), EDST,

Faculté de Santé Publique, Lebanese University

Tripoli, Lebanon

[h] Dr. Z. Fajloun

Laboratory of Applied Biotechnology

Azm Center for Research in Biotechnology and its Applications

EDST \& Faculty of Science III, Lebanese University

Tripoli, Lebanon

E-mail: ziad.fajloun@ul.edu.lb

[i] Dr. B. Baratte, Dr. S. Ruchaud, Dr. S. Bach

Sorbonne Universités, UPMC Univ Paris 06, CNRS USR3151

'Protein Phosphorylation and Human Disease' Unit

Plateforme de criblage KISSf, Station Biologique de Roscoff

Place Georges Teissier, 29688 Roscoff, France

E-mail: bach@sb-roscoff.fr

Supporting information for this article is given via a link at the end of the document.

Abstract: Various aromatic ketones were first functionalized next to the carbonyl function by deprotolithiation in the presence of a zinc salt followed by iodolysis. The outcome of the reactions was

analyzed, and in particular their regioselectivity in the light of the calculated $\mathrm{p} K_{\mathrm{a}}$ values. The various halogenated ketones were next involved in copper-catalyzed two-fold C-N bond formation in order to obtain fused systems based on 2-aminopyrimidines. Besides potential antibacterial effect, reached 2-aminobenzothiopyrano[4,3,2de]quinazoline proved to inhibit PIM1 $\left(\mathrm{IC}_{50}: 0.61 \mu \mathrm{M}\right)$ and CDK2/cyclin A ( $\left.\mathrm{IC}_{50}: 2.0 \mu \mathrm{M}\right)$ kinases.

\section{Introduction}

Aromatic ketones halogenated next to the carbonyl function are important key intermediates in organic synthesis. They can be used to access various scaffolds for applications in the fields of medicina $^{[1]}$ and material ${ }^{[2]}$ chemistry. Combining $\mathrm{C}-\mathrm{N}$ bond formation ${ }^{[3]}$ with condensation reactions ${ }^{[4]}$ can provide an access from such ketones to elaborated fused systems based on 2 aminopyrimidines, potentially endowed with various biological properties. ${ }^{[5]}$ However, in spite of their interest, few efficient methods presently exist to selectively introduce a halogen onto an aroyl group next to the carbonyl. Unlike electrophilic halogenation, that in general requires the presence of additional directing substituents, ${ }^{[1 \mathrm{~b}, 1 \mathrm{c}, 2]}$ transition-metal-catalyzed $\mathrm{C}-\mathrm{H}$ bond halogenation using $N$-halo succinimides as oxidants can regioselectively provide aromatic ketones halogenated next to the carbonyl. Indeed, rhodium(III)-catalyzed bromination or iodination can be performed in the presence of catalytic silver hexafluoroantimonate $(\mathrm{V})$, and stoichiometric pivalic acid or copper acetate ${ }^{[6]}$ whereas palladium-catalyzed chlorination can be achieved in the presence of triflic acid and potassium persulfate. ${ }^{[7]}$ The former has not been applied to diaryl ketones ${ }^{[6]}$ and the latter showed a coordination-driven regioselectivity. ${ }^{[7}$ We developed an alternative way based on polar-reagentmediated deprotonative metalation in order to access various iodinated aromatic ketones.

We recently communicated our preliminary studies centered on the functionalization of pyridyl ketones by deprotolithiation-in situ zincation. ${ }^{[8]}$ We here detail our investigations in order to better understand the behavior of the ketone function as directing group. Because $\mathrm{CH}$ acidity concept helps understand deprotometalation outcomes, $\mathrm{p} K_{\mathrm{a}}$ values in THF (THF = tetrahydrofuran) solution were calculated by means of quantum chemistry within the DFT framework using an approach elaborated earlier ${ }^{[8,9]}$ 


\section{Results and Discussion}

Deprotolithiation has been largely used to activate aromatic compounds and make them react with a large range of electrophiles. ${ }^{[10]}$ Whereas heteroatom-containing groups can help when connected to the aromatic ring, either by acidification (electron-withdrawing effect),${ }^{[10 e]}$ or by metal coordination, ${ }^{[11]}$ they can also modify the reaction outcome by reacting with the base or the generated aromatic lithium species as is the case for ketone functions. ${ }^{[12]}$

Because of their low compatibility with organolithiums, ketone-containing substrates have only been sporadically deprotometalated. Chromone and $\mathrm{N}$-methyl quinolone could be deprotozincated using TMP-based zinc amides (TMP $=2,2,6,6$ tetramethylpiperidino) either next to the carbonyl (3 position) or to the other heteroatom (2 position), respectively in the absence or presence of $\mathrm{MgCl}_{2}$, resulting of the Lewis acid coordination by the ketone. ${ }^{[13]}$ Pyronones ${ }^{[13 a, 14]}$ were functionalized at $\mathrm{C} 3$ by using TMPZnCl. $\mathrm{LiCl}$ whereas thiochromone ${ }^{[13 \mathrm{a}]}$ was attacked at $\mathrm{C} 2$ by the same reagent. Tropolones were deprotometalated next to the function upon treatment by TMPZnCl. LiCl. ${ }^{[15]}$ Fivemembered heteroaromatic aldehydes ${ }^{[16]}$ were similarly functionalized using TMP-based zinc amides. In contrast, very few diaryl ketones were concerned: benzoyl behaved as tolerated group in the TMPMgCl$\cdot \mathrm{LiCl}$-mediated deprotonation of a polysubstituted diethyl 1,3-phenylenedicarboxylate, ${ }^{[17]}$ whereas it only acted as directing group in the deprotometalation of benzophenone using a lithium-cadmium base. ${ }^{[18]}$

Ketones are compatible to some extent with hindered lithium amides such as LiTMP, as shown for example in the generation of lithium enolates. In contrast, these functions are attacked by organolithiums. ${ }^{[19]}$ Thus, to tackle the compatibility issue between organolithiums and ketones, we planned LiTMPmediated deprotometalation in the presence of a zinc-based in situ trap. Studies have shown that it is possible to employ species such as $\mathrm{Zn}(\mathrm{TMP})_{2}{ }^{[20]}$ and $\mathrm{ZnCl}_{2} \cdot 2 \mathrm{LiCl}^{[21]}$ to intercept polar arylmetals. Within this study, we chose $\mathrm{ZnCl}_{2} \cdot \mathrm{TMEDA}^{[22]}$ (TMEDA = N,N,N',N'-tetramethylethylenediamine) as in situ trap to attempt deprotolithiation followed by 'trans-metal trapping, ${ }^{\text {,23] }}$ and iodolysis from various diaryl ketones (Table 1).

Xanthone dimethyl acetal can be dimetalated next to the pyran oxygen ( 4 and 5 positions) in tetrahydropyran at $-13^{\circ} \mathrm{C}$ upon treatment by butyllithium ( 3 equiv.) in the presence of potassium tert-butoxide ( 3 equiv.), a result evidenced by subsequent trapping with iodomethane. ${ }^{[24]}$ Treatment of xanthone (1a) in THF containing $\mathrm{ZnCl}_{2}$. TMEDA (1 equiv.) with LiTMP (1.5 equiv.) at $-55^{\circ} \mathrm{C}$ for $15 \mathrm{~min}$ and then iodine $(1.5$ equiv.) provided the 1 -iodo derivative $2 \mathbf{a}$ in $72 \%$ yield (entry 1 ). Thioxanthone (1) $\mathbf{b}$ ) was similarly converted to afford $\mathbf{2 b}$ (entry 2 ). The calculated $p K_{a}$ values of $\mathbf{1} \mathbf{a}, \mathbf{b}$ can help rationalize this regioselectivity change and explain the directing group properties of the ketone. Compared with those next to the ketone function (1 and 8 positions), $\mathrm{CH}$ acidities next to the pyran or thiopyran heteroatom (4 and 5 positions) are higher. The observed deprotonation at the 1 position (beyond thermodynamic acidity ${ }^{[11]}$ could result from (i) ketone coordination to lithium, with induced acidity increase, (ii) favored approach of the base, and/or (iii) stabilization. Indeed, when compared with esters and $N, N$-dialkylcarboxamides, the coordination ability of the ketone carbonyl group is known to be higher. $^{[7]}$

Table 1. Substrates 1 and their calculated $p K_{\mathrm{a}}$ (THF) values, and iodinated aromatic ketones 2 obtained by deprotometalation-iodination.

$$
\begin{aligned}
& \text { 1) } \mathrm{ZnCl}_{2} \cdot \operatorname{TMEDA}(1 \text { equiv.) } \\
& \text { 2) } \mathrm{LiTMP}(1.5 \text { equiv.) } \\
& \mathrm{THF},-55^{\circ} \mathrm{C}, 15 \mathrm{~min}
\end{aligned}
$$

Ketone 1

3) $I_{2}(1.5$ equiv.) $-55^{\circ} \mathrm{C}$ to r.t.

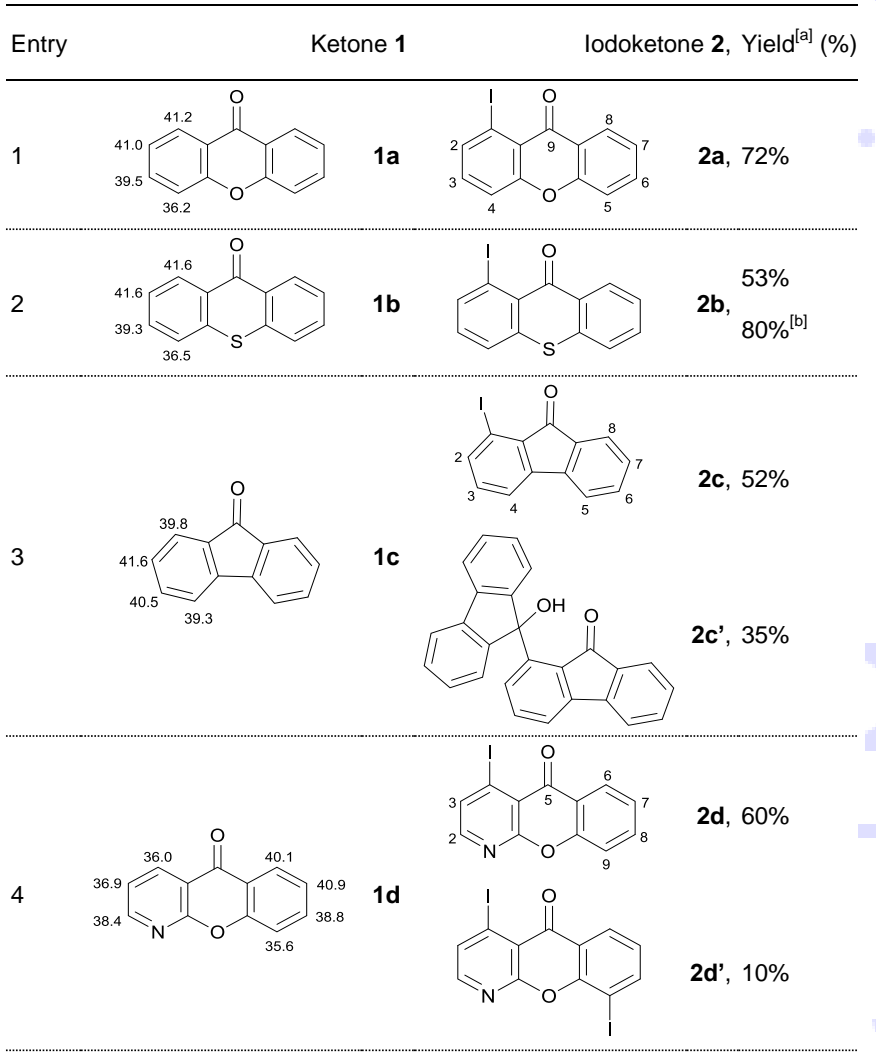
5 (1) [b] 


(1)

[a] After purification by column chromatography. [b] Reaction carried out at $-30^{\circ} \mathrm{C}$ instead of $-55^{\circ} \mathrm{C}$. [c] Other products also formed but could not be isolated or even identified. [d] A similar yield was obtained by using 2 equiv. of $\mathrm{ZnCl}_{2}$. TMEDA. [e] Reaction carried out by using 2 equiv. (instead of 1.5 equiv.) of LiTMP. [f] By performing the reaction at $-70^{\circ} \mathrm{C}$ (instead of $-55^{\circ} \mathrm{C}$ ).

From xanthone (1a) to fluorenone (1c), changes were noticed. Thus, whereas the iodide $\mathbf{2 a}$ was isolated in $72 \%$ yield (together with recovered starting material), the 1-iodo derivative 2c was obtained in $52 \%$ yield due to the competitive formation of the keto-alcohol 2c' (entry 3). The latter had previously been isolated in $63 \%$ yield by reacting fluorenone (1c) with the base prepared in situ from $\mathrm{ZnCl}_{2}$.TMEDA and LiTMP in a 1:3 ratio, and supposed to be LiTMP-Zn(TMP $)_{2},{ }^{[20]}$ with $\mathrm{Zn}(\mathrm{TMP})_{2}$ acting as in situ trap. ${ }^{[25]}$ Because arylzincs hardly react with ketones, ${ }^{[26]}$ $\mathbf{2} \mathbf{c}^{\prime}$ would rather result from an addition of the generated 1lithiofluorenone onto starting 1c. At first sight, this is surprising since fluorenone (1c) benefits from a more favorable $\mathrm{CH}$ acidity at its 1 position than xanthone (1a). That such a competitive reaction does not take place from 1a is in favor of an impact of the ketone carbonyl orientation on the stabilization of the lithio compound before its interception by 'trans-metal trapping'. This is also in accordance with data previously recorded with $\mathrm{N}, \mathrm{N}$ dialkylcarboxamides as deprotolithiation directing groups. Indeed, from studies performed on benzamides, Beak and coworkers suggest a correlation between the reaction efficiency and the distance from the directing group oxygen to the ortho hydrogen, as well as an optimal distance to accommodate the base effectively in the transition structure. ${ }^{[27]}$

By switching from symmetrical xanthone (1a) to the dissymmetrical azaxanthone 1d, one moves from two different potential deprotometalation sites to four. Nevertheless, from the two $\mathrm{CH}$ sites next to the carbonyl group, the pyridine 4 position is clearly the more acidified, and it is logically attacked to give the 4-iodo derivative $\mathbf{2 d}$ in $60 \%$ yield (entry 4). The corresponding thio analog $2 \mathrm{e}$ was obtained in $60 \%$ yield by reacting the azathioxanthone $1 \mathrm{e}$ under the same conditions (entry 5 ). In the case of $\mathbf{1 d}$, the diiodide $\mathbf{2} \mathbf{d}$ ' resulting from a twofold deprotonation at the 4 and 9 positions was also isolated (entry 4); that such a diiodo derivative is not formed from $\mathbf{1 e}$ might result from a lower propensity of sulfur to coordinate lithium, when compared with oxygen.

Due to its strong ability to coordinate lithium, the pyridine nitrogen is a good candidate to compete with the ketone oxygen in coordinating metals. Thus, it is not surprising that the azafluorenone $\mathbf{1 f}$ is also attacked at its 9 position (to afford $\mathbf{2} \mathbf{f}^{\prime}$ in $20 \%$ yield) in addition to the 4 one giving $2 f$ in $33 \%$ yield (entry 6 ). The second functionalization at the 9 position might happen after a first deprotolithiation-'trans-metal trapping' at the 4 position, as previously observed from other heterocycles. ${ }^{[9 a, 28]}$

Because of their $\pi$-deficiency, benzoylpyridines are more sensitive toward nucleophiles than simpler aryl ketones; not only the function, but also the pyridine ring (and in particular when the ketone function activates its 2 and 4 positions toward nucleophilic attack) can be subjected to the addition of organolithiums. From 2-benzoylpyridine $(\mathbf{1 g})$, optimization of the reaction conditions was carried out in THF containing $\mathrm{ZnCl}_{2}$.TMEDA (1 equiv.) by using four different reaction temperatures, between -70 and $-10{ }^{\circ} \mathrm{C}$, and four different amounts of LiTMP, between 1 and 3 equiv. The best results were observed when 1.5 equiv. of LiTMP were employed at $-30{ }^{\circ} \mathrm{C}$ for $15 \mathrm{~min}$ before interception with iodine to furnish the 3 iodo derivative $\mathbf{2 g}$ in $50 \%$ yield (entry 7 ). The reaction from $4-$ benzoylpyridine (1h) was performed as for its 2-isomer, but using 2 equiv. of LiTMP; under these conditions, the 3 -iodo derivative $\mathbf{2} \mathbf{h}$ was isolated in $45 \%$ yield (entry 8 ).

Among the three different benzoylpyridines used $\mathbf{1 g - i}$, 3benzoylpyridine (1i) is by far the more sensitive due to its free 4 position next to the ketone function. ${ }^{[29]}$ To limit side nucleophilic attacks, the reaction has to be conducted at lower temperatures. Under the conditions used to make 1a-f react (reaction at $-50{ }^{\circ} \mathrm{C}$ ), the product $2 \mathbf{i}$ resulting from a metalation at the 4 position was isolated from a complex mixture in $30 \%$ yield. At $-70{ }^{\circ} \mathrm{C}$, the result was slightly improved, with $\mathbf{2 i}$ obtained in $37 \%$ yield (entry 9). Diiodides were suspected as side products in the course of the reactions coming from $\mathbf{1 g - i}$; unambiguously, such 
a derivative (2h') was obtained in $10 \%$ yield from $\mathbf{1 h}$ (entry 8 ).

The pyridine regioselective deprotonation of $\mathbf{1 g}-\mathbf{i}$ is in accordance with higher calculated $\mathrm{p} K_{\mathrm{a}}$ values for the phenyl ring. If the pyridine $p K_{\mathrm{a}}$ values might help understand regioselective deprotometalation next to the ketone in the case of $\mathbf{1 h}$ and $\mathbf{1 i}$, things are different for $\mathbf{1 g}$. Indeed, for the latter, the most acidic sites are rather the 4 and 5 positions whereas the reaction takes place at the 3 position flanked by the function (entries 7-9). It is thus of importance to take into account possible coordination of the present heteroatoms onto metals in order to have a better idea of the $\mathrm{p} K_{\mathrm{a}}$ values within premetalation complexes or transition structures. To this purpose, we calculated the $\mathrm{CH}$ acidities of the 1:1 complexes between 1 $\mathbf{g}$ - $\mathbf{i}$ and LiTMP (Figure 1). As it was proved earlier for methoxypyridines, ${ }^{[28 \mathrm{e}]}$ coordination by nitrogen was predicted to be slightly more effective than by oxygen (with the corresponding isomeric complexes being by $0.9 \mathrm{kcal} \mathrm{mol}^{-1}$ more stable for $1 \mathrm{~h}$ and 1.1 $\mathrm{kcal} \mathrm{mol}^{-1}$ for $\mathbf{1} \mathbf{i}$; in the case of $\mathbf{1 g}$, both atoms take part in the complexation). The metal coordination by the ring nitrogen lone pair drastically increases the pyridine $\mathrm{CH}$ acidity. Thus, in the case of $\mathbf{1 g}$.LiTMP, metal chelation strongly increases the acidity at the 3 position, adjacent to the ketone function. Similar coordination by the ketone oxygen can also operate to increase acidity, favor the approach of the base and stabilize the arylmetal species.
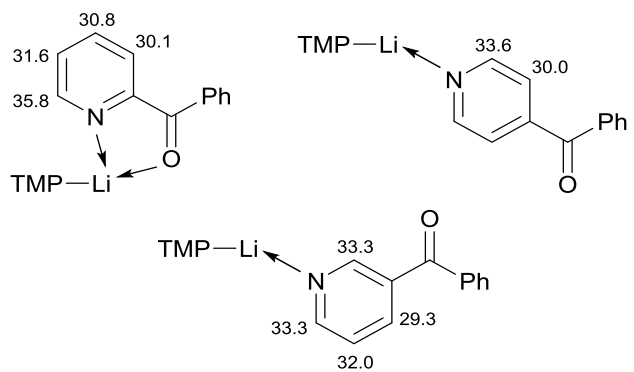

Figure 1. Selected calculated $\mathrm{p} K_{\mathrm{a}}$ values of the complexes between 1g. LiTMP (top, left), $\mathbf{1} \mathbf{h}$. LiTMP (top, right) and 1i. LiTMP (bottom).

To identify which metal, between lithium and zinc, is involved in such coordinations, we first compared spectral data of 3benzoylpyridine (1i), $\mathrm{ZnCl}_{2} \cdot \mathrm{TMEDA}$, TMEDA and 3benzoylpyridine (1i) in the presence of $\mathrm{ZnCl}_{2} \cdot T M E D A$. The IR, ${ }^{1} \mathrm{H}$ and ${ }^{13} \mathrm{C}$ NMR spectra recorded in $d^{8}$-THF showed no significant difference between 3-benzoylpyridine (1i) with and without $\mathrm{ZnCl}_{2} \cdot$ TMEDA on the one hand, and between $\mathrm{ZnCl}_{2} \cdot$ TMEDA in the presence or not of $1 \mathbf{i}$ on the other hand (e.g. $\sim 1 \mathrm{~cm}^{-1}$ for the $\mathrm{C}=\mathrm{O}$ IR absorption band; $\leq 0.1 \mathrm{ppm}$ for ${ }^{13} \mathrm{C}$ NMR chemical shifts). Because the chelating TMEDA is not displaced by addition of 3-benzoylpyridine (1i), and TMPZnCl. $\mathrm{LiCl}$ not capable of deprotonation at such low temperatures, ${ }^{[16 \mathrm{~b}, 16 \mathrm{c}, 30]}$ we can suggest that $\mathrm{ZnCl}_{2}$.TMEDA only operates after deprotolithiation and intercepts the generated aryllithium.

On this basis, the scope of our approach will be determined by the efficiency of the in situ traps employed, and by the stability of the transient lithiated arylketones involved. When present at pyridine 2 position, ${ }^{[31]}$ halogens are known to acidify the 4 position, and thus to stabilize a 4 -lithio derivative. This long-range effect, well-known for bromine ${ }^{[32]}$ also exists for chlorine $^{[33]}$ and fluorine. ${ }^{[28 \mathrm{e}, 34]}$ As a consequence, the deprotolithiation-transmetalation-iodolysis sequence carried out on the 2-halogenated 3-benzoylpyridines $\mathbf{1 j - m}$ offered more satisfactory yields $(63-78 \%$, entries $10-13)$ than from reference 3-benzoylpyridine (1i) $(30 \%$, entry 9$)$. Nevertheless, in spite of the presence of a stabilizing chloro group, the reaction from $\mathbf{1 n}$ proved more complex, only affording $\mathbf{2 n}$ in a modest $27 \%$ yield (entry 14). Unlike halogens, methoxy is not a suitable group to acidify long-range positions. ${ }^{[28 \mathrm{e}]}$ If the yield to convert $\mathbf{1 0}$ into $\mathbf{2 0}$ was found higher (88\% against $30 \%$ from $1 \mathbf{i}$ under similar reaction conditions, entry 15$)$, it might rather be related to the higher propensity of methoxy to make the pyridine ring less prone to nucleophilic attacks. ${ }^{[8]}$

In all the above examples, functionalization takes place at a position adjacent to the ketone function. It was thus of interest to attempt the reaction on a substrate benefiting from a more activated site. To this purpose, we chose 2-benzoylthiophene (1p) for which the most acidic site is next to sulfur. When submitted to LiTMP in the presence of $\mathrm{ZnCl}_{2}$. TMEDA as before, the iodide $2 p$ logically resulting from proton abstraction at the thiophene 5 position was isolated in $80 \%$ yield (entry 16 ).

Until now, we used iodine to evidence the formation of deprotometalated species, the resulting iodoketones being of high relevance to perform further functionalization. It is also of interest to combine deprotometalation with Negishi-type crosscoupling $^{[35]}$ in order to directly connect aryl groups. In the presence of catalytic amounts of palladium(II) chloride and 1,1'diphenylphosphinoferrocene (dppf), and under THF reflux, the deprotozincated product coming from xanthone (1a) was coupled with 2-chloropyridine to afford the derivative $\mathbf{3 a}$ in $76 \%$ yield (Scheme 1). The products $\mathbf{2 d}, \mathbf{2 f}, \mathbf{2} \mathbf{g}, \mathbf{2 h}, \mathbf{2} \mathbf{h}, \mathbf{2 i}, \mathbf{2 j}, \mathbf{2 k}, \mathbf{2} \mathbf{l}$, $2 \mathrm{~m}, 2 \mathrm{o}, 2 \mathrm{p}$ and $\mathbf{3 a}$ were identified unambiguously by $X$-ray diffraction (see Supporting information).

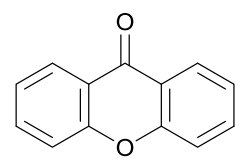

$1 \mathrm{a}$

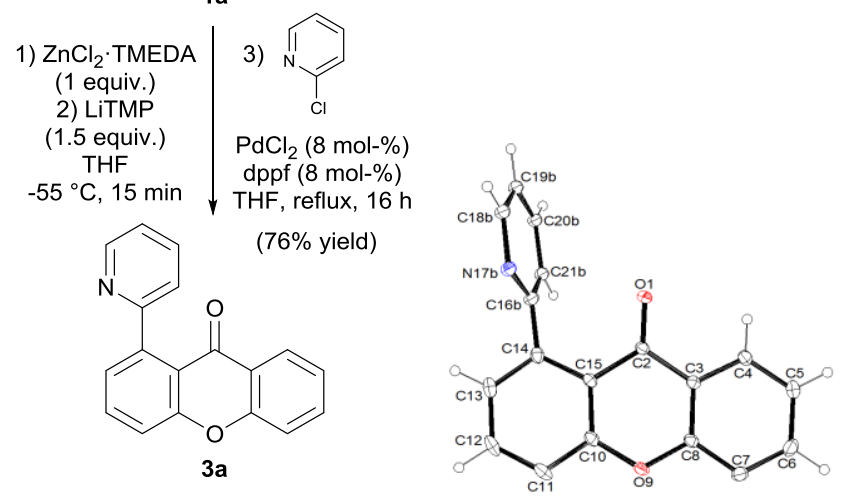

Scheme 1. Zincation of xanthone (1a) using LiTMP in the presence of $\mathrm{ZnCl}_{2} \cdot$ TMEDA followed by palladium-catalyzed cross-coupling to afford 3a; ORTEP diagram (30\% probability) of compound $\mathbf{3 a}$. 
Pyridopyrimidine is a core present in compounds of medicinal importance for their anticancer, CNS, fungicidal, antiviral, anti-inflammatory, antimicrobial and antibacterial properties. ${ }^{[36]}$ To access such compounds, efficient synthetic methods are required. The two-fold functionalization of the bifunctional substrates 2 combining $\mathrm{C}-\mathrm{N}$ bond formation ${ }^{[3]}$ from the iodide with imine formation ${ }^{[4]}$ from the ketone appears as an attracting way to reach original fused systems based on pyrido[2,3-e]pyrimidines.

To this end, we first considered the reaction between 2benzoyl-3-iodopyridine $(\mathbf{2 g}$ ) and 3-amino-1,2,4-triazole (Table 2). Our attempt to obtain the $1,3,4,6,9 \mathrm{~b}$ pentaazacyclopenta[a]naphthalene $\mathbf{3 g} \mathbf{1}$ by simply heating the two coupling partners in the presence of a base (cesium carbonate) in DMF at $110^{\circ} \mathrm{C}$, as reported from 2-fluoro, 2-chloro and 2-bromo aryl ketones, ${ }^{[37]}$ completely failed (entry 1). The starting materials were also recovered upon treatment by cesium carbonate and catalytic copper(I) oxide in DMSO at $110^{\circ} \mathrm{C}$ (entry 2), which are suitable conditions for coupling iodopyridines. ${ }^{[38]}$ Only traces of the expected product $\mathbf{3 g} 1$ were detected by using potassium carbonate and catalytic copper(I) iodide in either ethylene glycol (entry 3), or DMF containing ethylenediamine as ligand (entry 4), which are appropriate conditions for reacting 2-bromobenzaldehydes and 2-bromoaryl ketones with 3-aminopyrazoles. ${ }^{[4 b]}$ Finally, by keeping copper(I) iodide, ${ }^{[4 b]}$ employing potassium triphosphate as base, ${ }^{[39]}$ and DMSO as solvent (no need of ligand) ${ }^{\left[{ }^{[3]}\right.}$ led to $\mathbf{3 g} \mathbf{1}$, which was isolated in $54 \%$ yield (entry 5 ; Figure 2 , left).

Table 2. Optimization of the conversion of 2-benzoyl-3-iodopyridine $(\mathbf{2 g})$ into 5-phenyl-1,3,4,6,9b-pentaazacyclopenta[a]naphthalene (3g1).<smiles>O=C(c1ccccc1)c1ncccc1I</smiles>

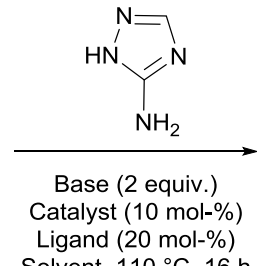

$2 \mathrm{~g}$<smiles>c1ccc(-c2nc3ncnn3c3cccnc23)cc1</smiles>

3g1

\begin{tabular}{cccccc}
\hline Entry & Base & Catalyst & Ligand & Solvent & Yield $^{[\mathrm{a}]}$ \\
\hline 1 & $\mathrm{Cs}_{2} \mathrm{CO}_{3}$ & - & - & $\mathrm{DMF}$ & - \\
\hdashline 2 & $\mathrm{Cs}_{2} \mathrm{CO}_{3}$ & $\mathrm{Cu}$ & & $\mathrm{DMSO}$ & - \\
\hdashline 3 & $\mathrm{~K}_{2} \mathrm{CO}_{3}$ & $\mathrm{Cul}$ & - & $\left(\mathrm{CH}_{2} \mathrm{OH}\right)_{2}$ & traces \\
\hdashline 4 & $\mathrm{~K}_{2} \mathrm{CO}_{3}$ & $\mathrm{Cul}$ & $\left(\mathrm{CH}_{2} \mathrm{NH}_{2}\right)_{2}$ & $\mathrm{DMF}$ & traces \\
\hdashline 5 & $\mathrm{~K}_{3} \mathrm{PO}_{4}$ & $\mathrm{Cul}$ & - & $\mathrm{DMSO}$ & $54 \%$ \\
\hline
\end{tabular}

These conditions in hand, we attempted the reactions between 2-benzoyl-3-iodopyridine $(\mathbf{2 g})$ and other diamines (Table 3). Besides 3-amino-1,2,4-triazole (entry 1), we chose for this purpose commercial 3-aminopyrazole (entry 2), 2aminobenzimidazole (entry 3 ) and guanidine (entry 4). Whereas the $4,6,7,11 \mathrm{~b}$-tetraazabenzo[c]fluorene $\mathbf{3 g} 3$ was obtained in a

$50 \%$ yield (entry 3 ; Figure 2, right) similar to $\mathbf{3 g} \mathbf{1}$ (entry 1 ), the 1,4,6,9b-tetraaza-cyclopenta[a]naphthalene $\mathbf{3 g} 2$ (entry 2) and 2aminopyrido[3,2- $d$ ]pyrimidine $\mathbf{4 g}$ (entry 4 ) were isolated in only $18 \%$ and $30 \%$ yield, respectively. For the latter, not only starting materials, but also deiodinated $\mathbf{1} \mathbf{g}$, were recovered.

Table 3. Conversion of the iodoketone $\mathbf{2 g}$ into fused systems based on pyrido[2,3-e]pyrimidines.
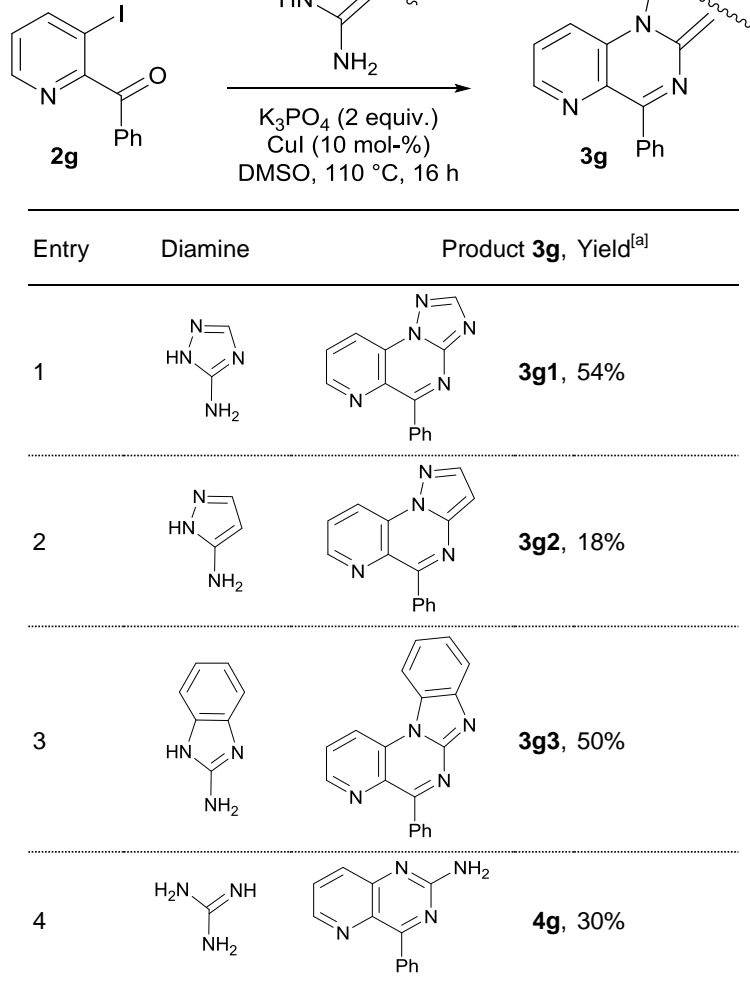

[a] After purification by column chromatography.

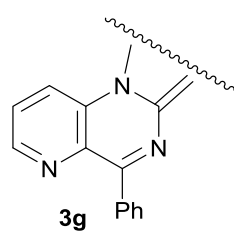

. 
The importance of that 2-aminopyrimidine motif in various biologically active scaffolds ${ }^{[5]}$ prompted us to identify the reasons behind this failure. Optimization of the amounts employed in the reaction between 2-benzoyl-3-iodopyridine $(\mathbf{2 g})$ and guanidine was thus performed. It was noticed that increasing the amounts of both guanidine (to 2 equiv. of the hydrochloride) and base (to 4 equiv.) could lead to $\mathbf{4 g}$ in an improved $77 \%$ yield (Table 4 , entry 1, Figure 3). Albeit in a somewhat lower yield of $61 \%$, the 2-aminopyrido[3,4-d]pyrimidine $\mathbf{4 h}$ was similarly formed from 4benzoyl-3-iodopyridine (2h) (entry 2 ).

In order to access the 2-aminopyrido[4,3-d]pyrimidines $4 \mathbf{i}$ and 40, for which the pyridine nitrogen is at the 6 position, we respectively involved in the reaction the 3-benzoyl-4iodopyridines $\mathbf{2} \mathbf{i}$ and $\mathbf{2 0}$. In spite of the known higher reactivity of 4-iodopyridines (higher partial positive charge on the carbon bearing the halogen) over 3-iodopyridines in copper-catalyzed C-N bond formation, ${ }^{[40]}$ similar yields of $68 \%$ and $65 \%$ were remarked from $\mathbf{2} \mathbf{i}$ and $\mathbf{2 0}$ (entries 3 and 4 , Figure 3).

To synthesize the isomer possessing the pyridine nitrogen at the 8 position, the 2-aminopyrido[2,3-d]pyrimidine $4 \mathbf{j}$, we rather reacted 3-benzoyl-2-fluoropyridine, easily prepared ${ }^{[41]}$ from 2fluoropyridine, with guanidine in the presence of potassium carbonate in dimethylacetamide at $135^{\circ} \mathrm{C}^{[42]}$ (entry 5, Figure 3).
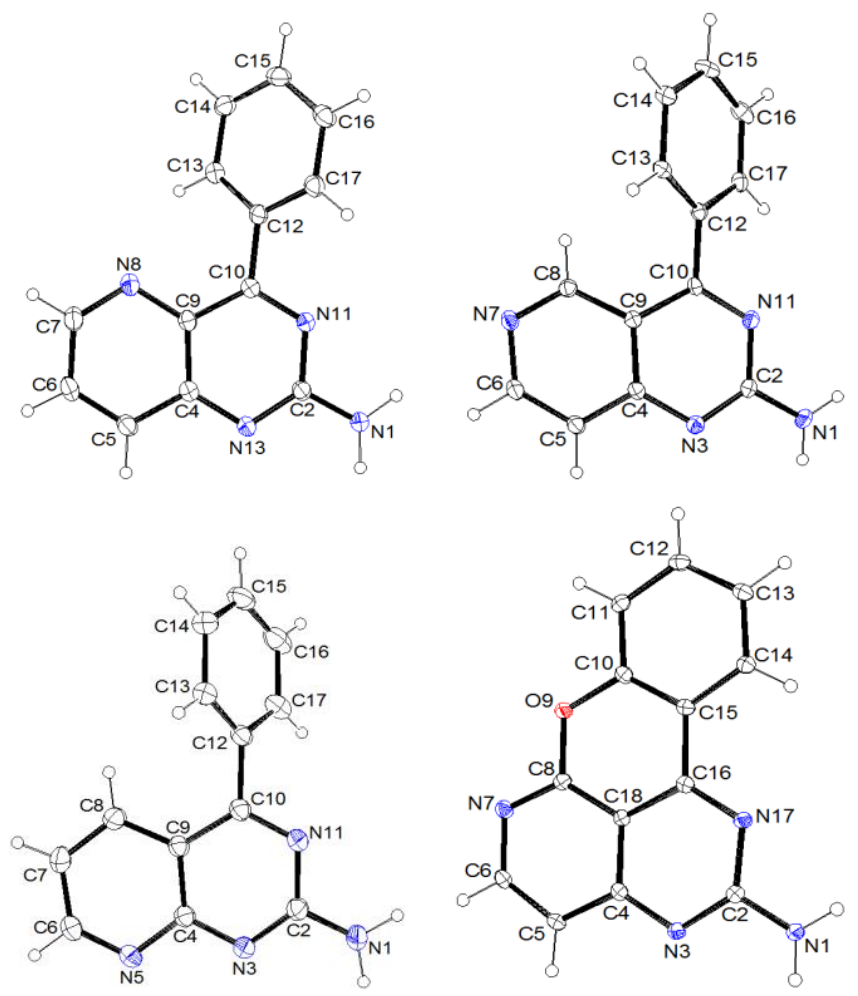

Figure 3. ORTEP diagrams (30\% probability) of compounds $\mathbf{4 g}, \mathbf{4 i}, \mathbf{4 j}$ and $\mathbf{4 d}$.

In spite of the widespread biological properties of quinazolines, the derived tetracyclic benzopyrano- ${ }^{[5 b]}$ and benzothiopyrano[4,3,2-de]quinazolines ${ }^{[43]}$ (for which a 1,3diazine ring is fused to a xanthene) have very rarely been synthesized. By applying the optimized method, we could convert the iodides $\mathbf{2 a}$ and $\mathbf{2} \mathbf{b}$ into the corresponding 2-amino derivatives $\mathbf{4 a}$ and $\mathbf{4 b}$ in high yields (entries 6 and 7 ).

Table 4. Conversion of the iodoketones 2 into fused systems based on 2aminopyrimidines.

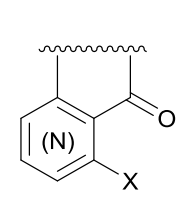
2

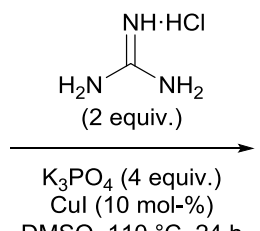

DMSO, $110^{\circ} \mathrm{C}, 24 \mathrm{~h}$

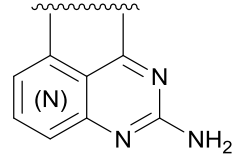

Entry Halogenoketone $2 \quad$ Product 4, Yield ${ }^{[\mathrm{a}]}$

(2)

3

(b)

6

8 9

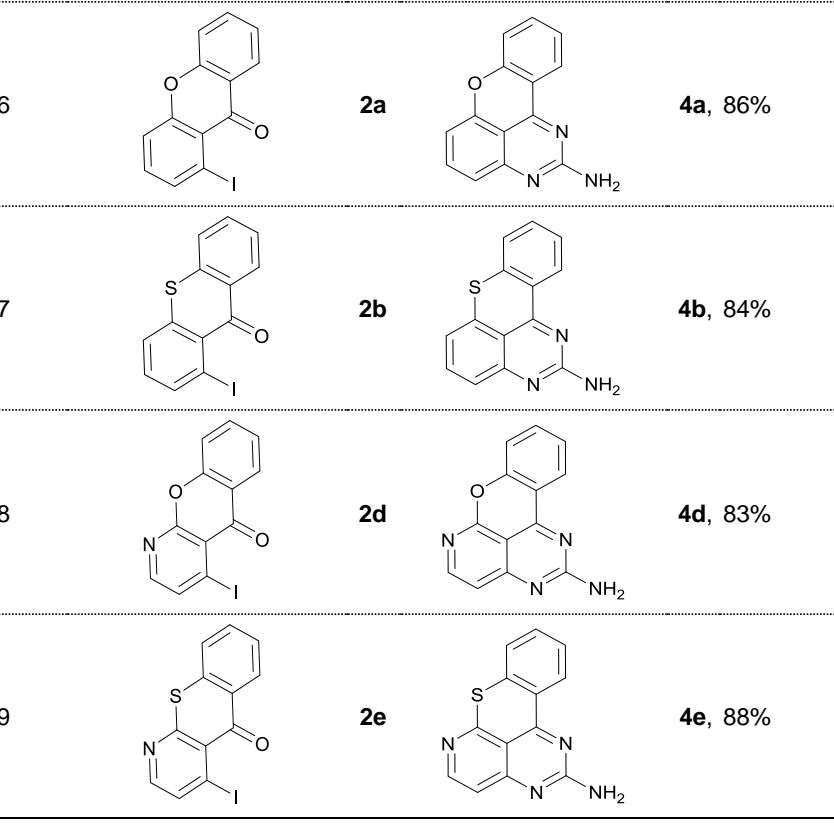

[a] After purification by column chromatography. [b] Reaction performed without $\mathrm{Cul}$ in the presence of $\mathrm{K}_{2} \mathrm{CO}_{3}$ instead of $\mathrm{K}_{3} \mathrm{PO}_{4}$, and using dimethylacetamide as solvent at $135^{\circ} \mathrm{C}$. 
The 7-oxa-1,3,6-triazabenz[de]anthracene skeleton has been reported once only ${ }^{[44]}$ whereas the 7-thia analog has never been described. We could prepare for the first time 2-amino derivatives, the tetracycles $\mathbf{4 d}$ and $\mathbf{4 e}$ (entries 8 and 9, Figure 3), which are potential candidates for biological studies.

All the pyrimidine-containing products were evaluated for their biological properties. They were first screened for their antimicrobial activity against bacteria and for their antifungal activity (Table 5). An effect on the microbial growth of strains of bacteria was noticed in the case of $\mathbf{4 g}, \mathbf{4 h}, \mathbf{4 i}, \mathbf{4 0}, \mathbf{4 j}, \mathbf{4 a}, \mathbf{4 b}, \mathbf{4 d}$ and $4 \mathbf{e}$, and a fairly broad spectrum of activity was precisely observed in the case of $\mathbf{4 j}$ and $\mathbf{4 b}$, highlighting their potential antibacterial effect.

Table 5. Antimicrobial and antifungal activity of the compounds $\mathbf{3 g} \mathbf{1}, \mathbf{3 g} \mathbf{2}, \mathbf{3 g} \mathbf{3}$, $4 \mathrm{~g}, 4 \mathrm{~h}, 4 \mathrm{i}, 40,4 \mathrm{j}, 4 \mathrm{a}, 4 \mathrm{~b}, 4 \mathrm{~d}$ and $4 \mathrm{e}^{[\mathrm{a}]}$

\begin{tabular}{|c|c|c|c|c|c|c|c|}
\hline 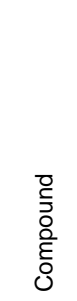 & 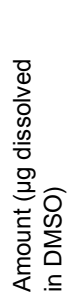 & 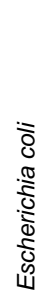 & 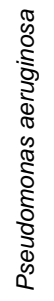 & 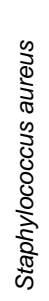 & 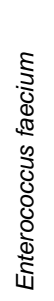 & 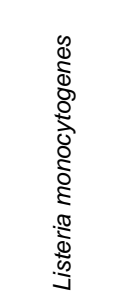 & 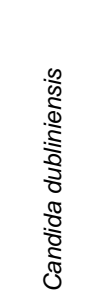 \\
\hline $3 g 1^{[b]}$ & 250 & \pm & \pm & 0 & \pm & 0 & 0 \\
\hline $3 \mathrm{~g} 2^{[\mathrm{b}]}$ & 200 & 0 & 0 & 0 & 0 & \pm & 0 \\
\hline $3 \mathbf{g}^{[\mathrm{b}]}$ & 200 & 0 & 0 & 0 & 0 & 0 & 0 \\
\hline $\mathbf{4 g}^{[\mathrm{c}]}$ & 250 & - & - & \pm & 13 & 24 & 19 \\
\hline $\mathbf{4 h}^{[c]}$ & 250 & - & - & - & 8 & 27 & - \\
\hline $4 i^{[c]}$ & 250 & - & - & \pm & 12 & 20 & 17 \\
\hline $40^{[c]}$ & 250 & 10 & \pm & \pm & 13 & 32 & 23 \\
\hline $4 j^{[b]}$ & 250 & 10 & 17 & \pm & 8 & - & 13 \\
\hline $4 a^{[c]}$ & 250 & - & - & \pm & 10 & 16 & \pm \\
\hline $\mathbf{4 b}^{[c]}$ & 250 & 15 & 17 & \pm & 13 & 17 & 17 \\
\hline $\mathbf{4 d}^{[\mathrm{c}]}$ & 250 & - & - & \pm & 10 & - & - \\
\hline $4 e^{[c]}$ & 250 & - & - & \pm & 12 & - & - \\
\hline & & 0 & 0 & 0 & 0 & 0 & 0 \\
\hline \multirow{2}{*}{\multicolumn{2}{|c|}{$\begin{array}{l}\text { Reference } \\
\text { compound }\end{array}$}} & 28 & 28 & 18 & 24 & 30 & 10 \\
\hline & & \multicolumn{2}{|c|}{$\begin{array}{c}\text { Ceftazidime } \\
(30 \mu \mathrm{g})\end{array}$} & \multicolumn{2}{|c|}{$\begin{array}{c}\text { Vancomycin } \\
(30 \mu \mathrm{g})\end{array}$} & $\begin{array}{l}\text { Ampicillin } \\
(25 \mu \mathrm{g})\end{array}$ & $\begin{array}{l}\text { Nystatin } \\
\text { (416 UI) }\end{array}$ \\
\hline
\end{tabular}

[a] The diameters of zones of inhibition are given in $\mathrm{mm}$. [b] $10 \mu \mathrm{L} /$ well. [c] 50 $\mu \mathrm{L} /$ well.
As evidenced in Table 6, all the compounds showed an antioxidant activity around $50 \%$. The hemolytic activity was tested for the compounds $\mathbf{4 g}, \mathbf{4 h}, \mathbf{4 i}, \mathbf{4 o}, \mathbf{4 j}, \mathbf{4 a}, \mathbf{4 b}, \mathbf{4 d}$ and $\mathbf{4 e}$ $(250 \mu \mathrm{g})$ that showed an antimicrobial activity. Small hemolytic activities below 15\% were recorded (data not shown). The absence or low toxicity on the human red blood cells, observed for products that have demonstrated an antimicrobial effect, highlights the value of their specific and selective antibacterial and antifungal effects and equally emphasizes a possible therapeutic interest of their application.

Table 6. Antioxidant activity of the compounds.

\begin{tabular}{|c|c|c|}
\hline Compound & $\mathrm{RSA}(\%)^{[\mathrm{a}]}$ at $\mathrm{t}=0 \mathrm{~min}$ & $\mathrm{RSA}(\%)^{[\mathrm{a}]}$ at $\mathrm{t}=30 \mathrm{~min}$ \\
\hline $\mathbf{4 g}$ & 42 & 46 \\
\hline $4 \mathrm{~h}$ & 43 & 47 \\
\hline $4 i$ & 43 & 49 \\
\hline 40 & 45 & 48 \\
\hline $4 j$ & 48 & 51 \\
\hline $4 a$ & 44 & 45 \\
\hline $4 b$ & 44 & 49 \\
\hline $4 d$ & 44 & 47 \\
\hline $4 e$ & 45 & 46 \\
\hline
\end{tabular}

[a] Percentage of the Radical Scavenger Activity.

Still in order to study the bioactivity of the synthesized compounds, we evaluated their bioactivity against a short panel of disease-related serine/threonine protein kinases: three human cyclin-dependent kinases (CDK2/Cyclin A, CDK5/p25 and CDK9/Cyclin T), human proto-oncogene PIM1, glycogensynthase kinase-3 (native GSK-3 purified from porcine brain), receptor-interacting protein 3 (RIPK3), human mitotic kinases Haspin and Aurora $\mathrm{B}$, and leishmania casein kinase 1 ( LmCK1 from Leishmania major).

Whereas none of the derivatives was shown to inhibit significantly CDK5/p25, CDK9/Cyclin T, GSK-3 and RIPK3, positive results were noticed with CDK2/Cyclin A, PIM1, LmCK1, Haspin and Aurora $B$ (Table 7). These first results were then verified by testing the dose-dependent effect of the small chemical compounds against a selected panel of kinases (Table 8).

The inhibition reported for $\mathbf{4 b}$ on PIM1 is interesting. Indeed, Horiuchi et al. showed that PIM1 kinase inhibition should be explored for developing targeted therapy against triple-negative breast tumors with elevated MYC expression. ${ }^{[45]}$ Moreover, despite the structural similarities between the three CDKs tested, $\mathbf{4 b}$ was shown to be selective for CDK2/Cyclin A. 
Table 7. Inhibitory activities of synthesized compounds against a short panel of five disease-related protein kinases. The table displays the remaining activities detected after treatment with $10 \mu \mathrm{M}$ of the tested compounds. Results are expressed in \% of maximal activity, i.e. measured in the absence of inhibitor. ATP concentration used in the kinase assays was $15 \mu \mathrm{mol} / \mathrm{L}$ (values are means, $n=2$ ). Kinases are from human origin unless specified: Lm, Leishmania major.

\begin{tabular}{lccccc}
\hline Compound & CDK2/Cyclin A & PIM1 & Haspin & Aurora B & LmCK1 \\
\hline $\mathbf{3 g 1}$ & 78 & 82 & 103 & 109 & 56 \\
\hline $\mathbf{3 g} \mathbf{n}$ & 57 & 87 & 117 & 49 & 61 \\
\hline $\mathbf{3 g} 3$ & 82 & 81 & 102 & 70 & 65 \\
\hline $\mathbf{4 g}$ & 83 & 104 & 107 & 98 & 111 \\
\hline $\mathbf{4 h}$ & 67 & 92 & 99 & 60 & 65 \\
\hline $\mathbf{4 i}$ & 65 & 95 & 98 & 80 & 61 \\
\hline $\mathbf{4 0}$ & 76 & 74 & 115 & 106 & 47 \\
\hline $\mathbf{4 j}$ & 78 & 85 & 102 & 64 & 58 \\
\hline $\mathbf{4 a}$ & 70 & 49 & 65 & 51 & $\mathbf{4 0}$ \\
\hline $\mathbf{4 b}$ & $\mathbf{4 1}$ & $\mathbf{3 2}$ & 59 & $\mathbf{4 0}$ & 55 \\
\hline $\mathbf{4 d}$ & 54 & 86 & 73 & $\mathbf{1 5}$ & $\mathbf{2 2}$ \\
\hline $\mathbf{4 e}$ & 59 & 77 & $\mathbf{4 1}$ & 45 & $\mathbf{3 7}$ \\
\hline
\end{tabular}

Table 8. Dose-dependent effect of the tested synthesized compounds on the kinase activities. The $\mathrm{IC}_{50}$ values are reported in $\mu \mathrm{M}$. Compounds showing less than $50 \%$ inhibition at $10 \mu \mathrm{M}$ were considered as inactive (values are means, $n=3)$.

\begin{tabular}{lccccc}
\hline Compound & CDK2/Cyclin A & PIM1 & Haspin & Aurora B & LmCK1 \\
\hline $\mathbf{3 g} 1$ & $>10$ & $>10$ & $>10$ & $>10$ & $>10$ \\
\hline $\mathbf{3 g} 2$ & $>10$ & $>10$ & $>10$ & $>10$ & $>10$ \\
\hdashline $\mathbf{3 g} 3$ & $>10$ & $>10$ & $>10$ & $>10$ & $>10$ \\
\hdashline $\mathbf{4 g}$ & $>10$ & $>10$ & $>10$ & $>10$ & $>10$ \\
\hdashline $\mathbf{4 h}$ & $>10$ & $>10$ & $>10$ & $>10$ & $>10$ \\
\hline $\mathbf{4 i}$ & $>10$ & $>10$ & $>10$ & $>10$ & $>10$ \\
\hdashline $\mathbf{4 0}$ & $>10$ & $>10$ & $>10$ & $>10$ & 4.5 \\
\hdashline $\mathbf{4 j}$ & $>10$ & $>10$ & $>10$ & $>10$ & $>10$ \\
\hdashline $\mathbf{4 a}$ & $>10$ & $>10$ & $>10$ & $>10$ & 6.5 \\
\hdashline $\mathbf{4 b}$ & $\mathbf{2 . 0}$ & $\mathbf{0 . 6 1}$ & $>10$ & $>10$ & $>10$ \\
\hdashline $\mathbf{4 d}$ & $>10$ & $>10$ & $>10$ & 1.9 & $\mathbf{1 0}$ \\
\hline $\mathbf{4 e}$ & $>10$ & $>10$ & $>10$ & $>10$ & $\mathbf{1 0}$ \\
\hline
\end{tabular}

\section{Conclusions}

We showed that the carbonyl group of aromatic ketones can be efficiently employed to induce deprotolithiation at an adjacent site. The reaction can be carried out by using a hindered nonnucleophilic lithium amide in the presence of a zinc salt that acts as in situ trap. The usefulness of aromatic ketones halogenated next to the carbonyl function was demonstrated by the synthesis of promising fused systems based on 2-aminopyrimidines.

\section{Experimental Section}

All the reactions were performed under an argon atmosphere. THF was distilled over sodium/benzophenone. Column chromatography separations were achieved on silica gel $(40-63 \mu \mathrm{m})$. Melting points were measured on a Kofler apparatus. IR spectra were taken on a PerkinElmer Spectrum 100 spectrometer. ${ }^{1} \mathrm{H}$ and ${ }^{13} \mathrm{C}$ Nuclear Magnetic Resonance (NMR) spectra were recorded on a Bruker Avance III spectrometer at $300 \mathrm{MHz}$ and $75 \mathrm{MHz}$, respectively. ${ }^{1} \mathrm{H}$ chemical shifts (ठ) are given in ppm relative to the solvent residual peak, ${ }^{13} \mathrm{C}$ chemical shifts are relative to the central peak of the solvent signal, ${ }^{[46]}$ and coupling constants $(\mathcal{J})$ are given in $\mathrm{Hz}$.

1-Azaxanthone (1d), ${ }^{[4]}$ 1-azathioxanthone (1e), ${ }^{[48]}$ 1-azafluorenone $(\mathbf{1 f}),{ }^{[49]}$ 3-benzoyl-2-fluoropyridine $(\mathbf{1 j}),{ }^{[41]}$ 3-benzoyl-2-chloropyridine $(\mathbf{1 k}),{ }^{[41]} \quad$ 2-chloro-3-(2-chlorobenzoyl)pyridine $\quad(\mathbf{1 I}),{ }^{[8]} \quad$ 2-chloro-3-(2methoxybenzoyl)pyridine $(\mathbf{1 m}),{ }^{[8]}$ 2-chloro-3-cinnamoylpyridine $(\mathbf{1 n}),{ }^{[8]} 3$ benzoyl-2-methoxypyridine (10), ${ }^{[41]}$ and $\mathrm{ZnCl}_{2} \cdot \mathrm{TMEDA}^{[22]}$ were prepared as described previously.

General procedure 1 for the synthesis of the aryl iodides 2 . To a stirred mixture of the required ketone $(1.0 \mathrm{mmol})$ and $\mathrm{ZnCl}_{2} \cdot \operatorname{TMEDA}(0.26$ $\mathrm{g}, 1.0 \mathrm{mmol})$ in THF $(3 \mathrm{~mL})$ at $-30{ }^{\circ} \mathrm{C}$ was added dropwise a solution of LiTMP (prepared by adding BuLi (about $1.6 \mathrm{M}$ hexanes solution, 1.5 mmol) to a stirred, cooled $\left(0^{\circ} \mathrm{C}\right)$ solution of 2,2,6,6-tetramethylpiperidine $(0.25 \mathrm{~mL}, 1.5 \mathrm{mmol})$ in THF $(3 \mathrm{~mL})$ and stirring for $5 \mathrm{~min})$ cooled at $30^{\circ} \mathrm{C}$. After $15 \mathrm{~min}$ at $-30^{\circ} \mathrm{C}$, a solution of $\mathrm{I}_{2}(0.38 \mathrm{~g}, 1.5 \mathrm{mmol})$ in THF (5 $\mathrm{mL}$ ) was introduced, and the mixture was stirred overnight before addition of an aqueous saturated solution of $\mathrm{Na}_{2} \mathrm{~S}_{2} \mathrm{O}_{3}(5 \mathrm{~mL})$ and extraction with AcOEt $(3 \times 20 \mathrm{~mL})$. The combined organic layers were dried over $\mathrm{MgSO}_{4}$, filtered and concentrated under reduced pressure. The crude product was purified by chromatography over silica gel (the eluent is given in the product description).

General procedure 2 for the synthesis of the aryl iodides 2. To a stirred mixture of the required ketone $(1.0 \mathrm{mmol})$ and $\mathrm{ZnCl}_{2} \cdot \mathrm{TMEDA}(0.26$ $\mathrm{g}, 1.0 \mathrm{mmol})$ in THF $(3 \mathrm{~mL})$ at $-55^{\circ} \mathrm{C}$ was added dropwise a solution of LiTMP (prepared by adding BuLi (about 1.6 M hexanes solution, 1.5 $\mathrm{mmol})$ to a stirred, cooled $\left(0^{\circ} \mathrm{C}\right)$ solution of 2,2,6,6-tetramethylpiperidine $(0.25 \mathrm{~mL}, 1.5 \mathrm{mmol})$ in THF $(3 \mathrm{~mL})$ and stirring for $5 \mathrm{~min})$ cooled at $-55^{\circ} \mathrm{C}$. After $15 \mathrm{~min}$ at $-55^{\circ} \mathrm{C}$, a solution of $\mathrm{I}_{2}(0.38 \mathrm{~g}, 1.5 \mathrm{mmol})$ in THF $(5 \mathrm{~mL})$ was introduced, and the mixture was stirred overnight before addition of an aqueous saturated solution of $\mathrm{Na}_{2} \mathrm{~S}_{2} \mathrm{O}_{3}(5 \mathrm{~mL})$ and extraction with AcOEt $(3 \times 20 \mathrm{~mL})$. The combined organic layers were dried over $\mathrm{MgSO}_{4}$, filtered and concentrated under reduced pressure. The crude product was purified by chromatography over silica gel (the eluent is given in the product description).

General procedure 3 for the synthesis of the aryl iodides 2. To a stirred mixture of the required ketone $(1.0 \mathrm{mmol})$ and $\mathrm{ZnCl}_{2} \cdot \mathrm{TMEDA}(0.26$ $\mathrm{g}, 1.0 \mathrm{mmol})$ in $\mathrm{THF}(3 \mathrm{~mL})$ at $-30{ }^{\circ} \mathrm{C}$ was added dropwise a solution of LiTMP (prepared by adding BuLi (about 1.6 M hexanes solution, 2.0 mmol) to a stirred, cooled $\left(0^{\circ} \mathrm{C}\right)$ solution of 2,2,6,6-tetramethylpiperidine (0.33 mL, $2.0 \mathrm{mmol})$ in THF (3 mL) and stirring for $5 \mathrm{~min})$ cooled at $30{ }^{\circ} \mathrm{C}$. After $15 \mathrm{~min}$ at $-30^{\circ} \mathrm{C}$, a solution of $\mathrm{I}_{2}(0.51 \mathrm{~g}, 2.0 \mathrm{mmol})$ in THF (5 $\mathrm{mL})$, and the mixture was stirred overnight before addition of an aqueous saturated solution of $\mathrm{Na}_{2} \mathrm{~S}_{2} \mathrm{O}_{3}(5 \mathrm{~mL})$ and extraction with AcOEt $(3 \times 20$ $\mathrm{mL}$ ). The combined organic layers were dried over $\mathrm{MgSO}_{4}$, filtered and concentrated under reduced pressure. The crude product was purified by 
chromatography over silica gel (the eluent is given in the product description)

\section{General procedure 4 for the synthesis of the fused systems based on pyrido[2,3-e]pyrimidines $3 \mathrm{~g}$. A mixture of Cul $(20 \mathrm{mg}, 0.10 \mathrm{mmol})$, the required amine $(1.2 \mathrm{mmol}), \mathrm{K}_{3} \mathrm{PO}_{4}(0.44 \mathrm{~g}, 2.0 \mathrm{mmol})$, 2-benzoyl-3- iodopyridine $(2 \mathrm{~g}, 0.31 \mathrm{~g}, 1.0 \mathrm{mmol})$ and DMSO $(1.4 \mathrm{~mL})$ was degased and heated under argon and stirring at $110{ }^{\circ} \mathrm{C}$ for $16 \mathrm{~h}$. After filtration over celite (washing using AcOEt) and removal of the solvents, the crude product is purified by chromatography over silica gel (the eluent is given in the product description).}

\section{General procedure 5 for the synthesis of the fused systems based on 2-aminopyrimidines 4 . A mixture of Cul $(20 \mathrm{mg}, 0.10 \mathrm{mmol})$, guanidine hydrochloride $(0.19 \mathrm{~g}, 2.0 \mathrm{mmol}), \mathrm{K}_{3} \mathrm{PO}_{4}(0.88 \mathrm{~g}, 4.0 \mathrm{mmol})$, the required halogenopyridine $(1.0 \mathrm{mmol})$ and $\mathrm{DMSO}(0.5 \mathrm{~mL})$ was degased and heated under argon at $110^{\circ} \mathrm{C}$ for $24 \mathrm{~h}$. After filtration over celite (washing using AcOEt) and removal of the solvents, the crude product is purified by chromatography over silica gel (the eluent is given in the product description).}

1-lodo-9-xanthone (2a). The general procedure 2 using 9-xanthone (1a $0.20 \mathrm{~g}$ ) gave 2a (eluent: heptane- $\mathrm{CH}_{2} \mathrm{Cl}_{2} 100: 0$ to $80: 20$ ) in $72 \%$ yield $(0.23 \mathrm{~g})$ as a pale yellow powder: $\mathrm{mp} 176{ }^{\circ} \mathrm{C}$ (lit. ${ }^{[24]} 172-173.5{ }^{\circ} \mathrm{C}$ ); IR (ATR): 663, 752, 777, 849, 903, 931, 1108, 1147, 1161, 1234, 1255, $1297,1328,1346,1421,1443,1466,1554,1590,1612,1661,3065 \mathrm{~cm}$ 1; ${ }^{1} \mathrm{H} \mathrm{NMR}\left(\mathrm{CDCl}_{3}\right) \delta 7.27$ (dd, $1 \mathrm{H}, J=8.4$ and $7.8 \mathrm{~Hz}$ ), 7.36 (ddd, $1 \mathrm{H}, J=$ $8.1,7.2$ and $0.9 \mathrm{~Hz}), 7.41(\mathrm{dm}, 1 \mathrm{H}, J=9.0 \mathrm{~Hz}), 7.48(\mathrm{dd}, 1 \mathrm{H}, J=8.4$ and $1.2 \mathrm{~Hz}$ ), 7.70 (ddd, $1 \mathrm{H}, J=8.7,7.2$ and $1.8 \mathrm{~Hz}$ ), 8.00 (dd, $1 \mathrm{H}, J=7.6$ and $1.1 \mathrm{~Hz}$ ), 8.31 (ddd, $1 \mathrm{H}, J=8.1,1.8$ and $0.5 \mathrm{~Hz}$ ); ${ }^{13} \mathrm{C} \mathrm{NMR}\left(\mathrm{CDCl}_{3}\right) \delta 91.3$ $(\mathrm{C}), 117.7(\mathrm{CH}), 119.1(\mathrm{CH}), 120.1(\mathrm{C}), 121.3(\mathrm{C}), 124.3(\mathrm{CH}), 127.3$ $(\mathrm{CH}), 134.7(\mathrm{CH}), 135.0(\mathrm{CH}), 138.6(\mathrm{CH}), 154.9(\mathrm{C}), 156.8(\mathrm{C}), 175.4$ (C). These data are similar to those reported previously. ${ }^{[24]}$

1-lodo-9-thioxanthone $(\mathbf{2 b})^{[25,50]}$ The general procedure 2 using 9thioxanthone (1b, $0.22 \mathrm{~g}$ ) gave 2b (eluent: heptane- $\mathrm{CH}_{2} \mathrm{Cl}_{2}$ 100:0 to $80: 20)$ in $53 \%$ yield $(0.18 \mathrm{~g})$ as a greenish powder: $\mathrm{mp} 156-158{ }^{\circ} \mathrm{C}$; IR (ATR): 664, 711, 745, 777, 923, 1080, 1159, 1241, 1300, 1425, 1537, 1573, 1589, 1641, $3062 \mathrm{~cm}^{-1} ;{ }^{1} \mathrm{H}$ NMR $\left(\mathrm{CDCl}_{3}\right) \delta 7.10(\mathrm{t}, 1 \mathrm{H}, J=7.8 \mathrm{~Hz})$, 7.41-7.47 (m, 2H), 7.52-7.60 (m, $2 \mathrm{H}), 8.14(\mathrm{dd}, 1 \mathrm{H}, J=7.5$ and $1.2 \mathrm{~Hz})$, $8.47(\mathrm{dm}, 1 \mathrm{H}, J=8.1 \mathrm{~Hz}) ;{ }^{13} \mathrm{C} \mathrm{NMR}\left(\mathrm{CDCl}_{3}\right) \delta 94.8(\mathrm{C}), 125.5(\mathrm{CH})$, $126.7(\mathrm{CH}), 126.8(\mathrm{CH}), 127.7(\mathrm{C}), 129.6(\mathrm{C}), 130.2(\mathrm{CH}), 131.8(\mathrm{CH})$, $132.3(\mathrm{CH}), 135.0(\mathrm{C}), 138.7(\mathrm{C}), 141.8(\mathrm{CH}), 179.5(\mathrm{C})$.

1-lodo-9-fluorenone (2c). The general procedure 2 using 9-fluorenone (1c, $0.18 \mathrm{~g}$ ) gave 2c (eluent: heptane-AcOEt $90: 10)$ in $52 \%$ yield $(0.16 \mathrm{~g}$ ) as a yellow powder: $\mathrm{mp} 1488^{\circ} \mathrm{C}$ (lit. ${ }^{[51]} 147-148.5^{\circ} \mathrm{C}$ ); IR (ATR): 733,747 , 784, 792, 918, 1056, 1085, 1126, 1149, 1186, 1257, 1281, 1295, 1437, $1563,1588,1606,1715,3048 \mathrm{~cm}^{-1} ;{ }^{1} \mathrm{H}$ NMR $\left(\mathrm{CDCl}_{3}\right) \delta 7.15(\mathrm{dd}, 1 \mathrm{H}, J=$ 8.1 and $7.5 \mathrm{~Hz}$ ), 7.33 (ddd, $1 \mathrm{H}, J=10.2,7.5$ and $4.8 \mathrm{~Hz}), 7.49-7.56(\mathrm{~m}$, $3 \mathrm{H}), 7.68-7.74(\mathrm{~m}, 2 \mathrm{H}) ;{ }^{13} \mathrm{C} \mathrm{NMR}\left(\mathrm{CDCl}_{3}\right) \delta 91.6(\mathrm{C}), 120.1(\mathrm{CH}), 120.2$ $(\mathrm{CH}), 124.7(\mathrm{CH}), 129.8(\mathrm{CH}), 134.0(\mathrm{C}), 134.1(\mathrm{C}), 135.0(\mathrm{CH}), 135.1$ (CH), 140.6 (CH), 142.0 (C), 147.2 (C), 191.8 (C). 9'-Hydroxy-1,9'-bi-9fluorenone $\left(\mathbf{2} c^{\prime}\right)$ was also isolated in $35 \%$ yield $(0.13 \mathrm{~g})$ as a yellow powder: $\mathrm{mp} 222-224^{\circ} \mathrm{C}$ (lit. ${ }^{[52]} 222-224^{\circ} \mathrm{C}$ ); IR (ATR): 686, 728, 753, 771 803, 909, 958, 1066, 1102, 1139, 1195, 1265, 1284, 1427, 1451, 1469, 1572, 1592, 1607, 1683, 2245, 3060, $3302 \mathrm{~cm}^{-1} ;{ }^{1} \mathrm{H} \mathrm{NMR}\left(\mathrm{CDCl}_{3}\right) \delta 6.47$ (dd, $1 \mathrm{H}, J=8.1$ and $0.9 \mathrm{~Hz}$ ), $7.11(\mathrm{dd}, 1 \mathrm{H}, J=8.1$ and $7.5 \mathrm{~Hz}$ ), 7.28 (td, $2 \mathrm{H}, J=7.5$ and $0.9 \mathrm{~Hz}), 7.33-7.42(\mathrm{~m}, 4 \mathrm{H}), 7.47-7.57(\mathrm{~m}, 4 \mathrm{H}), 7.70(\mathrm{~d}$, $2 \mathrm{H}, J=7.2 \mathrm{~Hz}), 7.78(\mathrm{~d}, 1 \mathrm{H}, J=7.2 \mathrm{~Hz}), 7.94(\mathrm{~s}, 1 \mathrm{H}) ;{ }^{13} \mathrm{C} \mathrm{NMR}\left(\mathrm{CDCl}_{3}\right) \delta$ $85.5(\mathrm{C}), 119.9(\mathrm{CH}), 120.3(2 \mathrm{CH}), 120.3(\mathrm{CH}), 124.7(2 \mathrm{CH}), 125.3(\mathrm{CH})$, $128.4(\mathrm{CH}), 128.4(2 \mathrm{CH}), 129.2(2 \mathrm{CH}), 129.6(\mathrm{CH}), 132.1(\mathrm{C}), 133.4(\mathrm{C})$, $135.5(\mathrm{CH}), 136.0(\mathrm{CH}), 139.9(2 \mathrm{C}), 144.3(\mathrm{C}), 146.8(\mathrm{C}), 148.8(\mathrm{C})$, $149.5(2 \mathrm{C}), 198.2(\mathrm{C})$
4-lodo-5H-benzopyrano[2,3-b]pyridin-5-one $\quad(\mathbf{2 d})^{[8]}$ The general procedure 2 using 1-azaxanthone (1d, $0.20 \mathrm{~g})$ gave $2 \mathrm{~d}$ (eluent: $\mathrm{CH}_{2} \mathrm{Cl}_{2}$ heptane $80: 20)$ in $60 \%$ yield $(0.19 \mathrm{~g})$ as a yellow powder: $\mathrm{mp} 190-192{ }^{\circ} \mathrm{C}$; IR (ATR): 728, 742, 761, 835, 922, 1085, 1115, 1183, 1219, 1248, 1274 $1318,1346,1367,1443,1464,1537,1557,1612,1659,1724,1978$, $2925 \mathrm{~cm}^{-1} ;{ }^{1} \mathrm{H}$ NMR $\left(\mathrm{CDCl}_{3}\right) \delta 7.40$ (ddd, $1 \mathrm{H}, J=8.1,6.9$ and $1.1 \mathrm{~Hz}$ ), $7.52(\mathrm{dq}, 1 \mathrm{H}, J=8.4$ and $0.6 \mathrm{~Hz}), 7.74(\mathrm{ddd}, 1 \mathrm{H}, J=8.7,6.9$ and $1.5 \mathrm{~Hz}$ ), $8.01(\mathrm{~d}, 1 \mathrm{H}, J=5.1 \mathrm{~Hz}), 8.17(\mathrm{~d}, 1 \mathrm{H}, J=4.8 \mathrm{~Hz}$ ), 8.26 (ddd, $1 \mathrm{H}, J=8.1$ 1.8 and $0.6 \mathrm{~Hz}) ;{ }^{13} \mathrm{C}$ NMR $\left(\mathrm{CDCl}_{3}\right) \delta 106.6(\mathrm{C}), 116.0(\mathrm{C}), 118.3(\mathrm{CH})$, $121.0(\mathrm{C}), 125.1(\mathrm{CH}), 127.2(\mathrm{CH}), 135.6(\mathrm{CH}), 135.8(\mathrm{CH}), 152.3(\mathrm{CH})$ 154.3 (C), 160.2 (C), 176.1 (C). 4,9-Diiodo-5H-benzopyrano[2,3b]pyridin-5-one $\left(\mathbf{2} \boldsymbol{d}^{\prime}\right)^{[8]}$ was also isolated in $10 \%$ yield $(45 \mathrm{mg})$ as a yellow powder: $\mathrm{mp} 262-264{ }^{\circ} \mathrm{C}$; IR (ATR): 734, 768, 920, 1019, 1101, 1266, $1369,1428,1444,1538,1655,1722,2924 \mathrm{~cm}^{-1} ;{ }^{1} \mathrm{H}$ NMR $\left(\mathrm{CDCl}_{3}\right) \delta 7.20$ (t, $1 \mathrm{H}, J=7.8 \mathrm{~Hz}$ ), 8.07 (d, $1 \mathrm{H}, J=4.8 \mathrm{~Hz}), 8.21-8.25(\mathrm{~m}, 2 \mathrm{H}), 8.29$ (dd, $1 \mathrm{H}, J=7.2$ and $1.5 \mathrm{~Hz}) ;{ }^{13} \mathrm{C}$ NMR $\left(\mathrm{CDCl}_{3}\right) \delta 85.2(\mathrm{C}), 106.9(\mathrm{C}), 115.7$ (C), $121.8(\mathrm{C}), 126.5(\mathrm{CH}), 127.7(\mathrm{CH}), 136.1(\mathrm{CH}), 145.6(\mathrm{CH}), 152.7$ $(\mathrm{CH}), 153.5(\mathrm{C}), 160.2(\mathrm{C}), 175.9(\mathrm{C})$

4-Iodo-5H-benzothiopyrano[2,3-b]pyridin-5-one (2e). ${ }^{[8]}$ The general procedure 2 using 1-azathioxanthone $(1 \mathrm{e}, 0.21 \mathrm{~g})$ gave $2 \mathrm{e}$ (eluent $\left.\mathrm{CH}_{2} \mathrm{Cl}_{2}\right)$ in $60 \%$ yield $(0.20 \mathrm{~g})$ as a yellow powder: $\mathrm{mp} 184-186{ }^{\circ} \mathrm{C}$; IR (ATR): 697, 724, 802, 922, 1079, 1166, 1232, 1301, 1319, 1348, 1412 , $1433,1521,1542,1588,1643,1945,2234,2929,3087 \mathrm{~cm}^{-1} ;{ }^{1} \mathrm{H}$ NMR $\left(\mathrm{CDCl}_{3}\right) \delta 7.51$ (ddd, $1 \mathrm{H}, J=8.4,6.9$ and $1.2 \mathrm{~Hz}$ ), 7.57 (ddd, $1 \mathrm{H}, J=8.1$, 1.5 and $0.6 \mathrm{~Hz}$ ), 7.66 (ddd, $1 \mathrm{H}, J=8.4,6.9$ and $1.5 \mathrm{~Hz}$ ), $8.11(\mathrm{~d}, 1 \mathrm{H}, J=$ $4.8 \mathrm{~Hz}), 8.17(\mathrm{~d}, 1 \mathrm{H}, J=5.1 \mathrm{~Hz}), 8.52(\mathrm{ddd}, 1 \mathrm{H}, J=8.1,1.5$ and $0.6 \mathrm{~Hz}$ ) ${ }^{13} \mathrm{C}$ NMR $\left(\mathrm{CDCl}_{3}\right) \delta 107.4(\mathrm{C}), 125.3(\mathrm{C}), 125.9(\mathrm{CH}), 127.1(\mathrm{CH}), 128.9$ (C), $130.4(\mathrm{CH}), 133.0(\mathrm{CH}), 135.2(\mathrm{C}), 136.8(\mathrm{CH}), 151.0(\mathrm{CH}), 159.7$ (C), $179.8(\mathrm{C})$.

4-lodo-5H-indeno[1,2-b]pyridin-5-one (2f) ${ }^{[8]}$ The general procedure 2 using 1-azafluorenone (1f, $0.18 \mathrm{~g})$ gave $2 \mathbf{f f}$ (eluent: heptane-AcOEt $80: 20)$ in $33 \%$ yield $(0.10 \mathrm{~g})$ as a yellow powder: $\mathrm{mp} 184{ }^{\circ} \mathrm{C}$; IR (ATR): $669,749,805,915,1042,1171,1265,1341,1379,1442,1550,1717 \mathrm{~cm}$ 1; ${ }^{1} \mathrm{H}$ NMR $\left(\mathrm{CDCl}_{3}\right) \delta 7.47(\mathrm{td}, 1 \mathrm{H}, J=7.2$ and $1.2 \mathrm{~Hz}), 7.61-7.67(\mathrm{~m}, 2 \mathrm{H})$, 7.76 (ddd, $1 \mathrm{H}, J=7.2,1.2$ and $0.6 \mathrm{~Hz}$ ), 7.87 (dt, $1 \mathrm{H}, J=7.5$ and $0.9 \mathrm{~Hz}$ ), $8.14(\mathrm{~d}, 1 \mathrm{H}, J=5.4 \mathrm{~Hz}) ;{ }^{13} \mathrm{C} \mathrm{NMR}\left(\mathrm{CDCl}_{3}\right) \delta 102.4(\mathrm{C}), 121.3(\mathrm{CH}), 124.5$ $(\mathrm{CH}), 129.4(\mathrm{C}), 131.7(\mathrm{CH}), 134.6(\mathrm{CH}), 135.0(\mathrm{C}), 135.7(\mathrm{CH}), 141.3$ (C), 152.7 (CH), 166.2 (C), 190.1 (C). 4,9-Diiodo-5H-indeno[1,2-b]pyridin5 -one $\left(\mathbf{2 f ^ { \prime }}\right)^{[8]}$ was also isolated in $20 \%$ yield $(87 \mathrm{mg})$ as a yellowish powder: mp $244^{\circ} \mathrm{C}$; IR (ATR): $659,693,761,783,824,924,1054,1102$, 1164, 1266, 1338, 1369, 1454, 1543, 1556, 1713, 2854, $2924 \mathrm{~cm}^{-1} ;{ }^{1} \mathrm{H}$ $\operatorname{NMR}\left(\mathrm{CDCl}_{3}\right) \delta 7.13(\mathrm{dd}, 1 \mathrm{H}, J=7.8$ and $7.2 \mathrm{~Hz}), 7.70(\mathrm{~d}, 1 \mathrm{H}, J=5.4 \mathrm{~Hz})$ $7.76(\mathrm{dd}, 1 \mathrm{H}, J=7.5$ and $1.1 \mathrm{~Hz}), 8.07(\mathrm{dd}, 1 \mathrm{H}, J=7.8$ and $2.0 \mathrm{~Hz}), 8.30$ $(\mathrm{d}, 1 \mathrm{H}, J=5.4 \mathrm{~Hz}) ;{ }^{13} \mathrm{C} \mathrm{NMR}\left(\mathrm{CDCl}_{3}\right) \delta 86.8(\mathrm{C}), 102.3(\mathrm{C}), 124.1(\mathrm{CH})$ $129.6(\mathrm{C}), 132.2(\mathrm{CH}), 134.8(\mathrm{CH}), 137.1$ (C), $141.4(\mathrm{C}), 147.5(\mathrm{CH})$, $151.8(\mathrm{CH}), 165.8(\mathrm{C}), 188.7(\mathrm{C})$.

2-Benzoyl-3-iodopyridine (2g). ${ }^{[8]}$ The general procedure 1 using 2benzoylpyridine (19, $0.18 \mathrm{~g}$ ) gave $\mathbf{2 g}$ (eluent: heptane-AcOEt 80:20) in $50 \%$ yield $(0.15 \mathrm{~g})$ as a yellow powder: $\mathrm{mp} 98-100{ }^{\circ} \mathrm{C}$; IR (ATR): 666 , 702, 739, 795, 939, 1011, 1064, 1165, 1287, 1316, 1416, 1450, 1595 $1674,3056 \mathrm{~cm}^{-1} ;{ }^{1} \mathrm{H}$ NMR $\left(\mathrm{CDCl}_{3}\right) \delta 7.16(\mathrm{dd}, 1 \mathrm{H}, J=8.1$ and $4.8 \mathrm{~Hz})$ 7.44-7.50 (m, 2H), 7.61 (tt, $1 \mathrm{H}, J=7.4$ and $1.4 \mathrm{~Hz}), 7.81-7.86(\mathrm{~m}, 2 \mathrm{H})$ $8.26(\mathrm{dd}, 1 \mathrm{H}, J=8.1$ and $1.2 \mathrm{~Hz}), 8.63(\mathrm{dd}, 1 \mathrm{H}, J=4.5$ and $1.5 \mathrm{~Hz}) ;{ }^{13} \mathrm{C}$ NMR $\left(\mathrm{CDCl}_{3}\right) \delta 89.8(\mathrm{C}), 125.6(\mathrm{CH}), 128.8(2 \mathrm{CH}), 130.6(2 \mathrm{CH}), 134.1$ $(\mathrm{CH}), 134.8(\mathrm{C}), 147.3(\mathrm{CH}), 148.1(\mathrm{CH}), 159.2(\mathrm{C}), 194.3(\mathrm{C})$.

4-Benzoyl-3-iodopyridine $(\mathbf{2 h}) .^{[8]}$ The general procedure 3 using 4 benzoylpyridine (1h, $0.18 \mathrm{~g}$ ) gave $\mathbf{2 h}$ (eluent: heptane-AcOEt 80:20) in $45 \%$ yield $(0.14 \mathrm{~g})$ as a yellow powder: $\mathrm{mp} 92-94^{\circ} \mathrm{C}$; IR (ATR): 683,701 , 728, 835, 938, 1011, 1082, 1175, 1262, 1281, 1316, 1394, 1448, 1580 , $1595,1669,3058 \mathrm{~cm}^{-1} ;{ }^{1} \mathrm{H} \mathrm{NMR}\left(\mathrm{CDCl}_{3}\right) \delta 7.19(\mathrm{dd}, 1 \mathrm{H}, J=4.8$ and 0.6 
$\mathrm{Hz}), 7.41-7.48(\mathrm{~m}, 2 \mathrm{H}), 7.61(\mathrm{tt}, 1 \mathrm{H}, J=7.4$ and $1.4 \mathrm{~Hz}), 7.72-7.76(\mathrm{~m}$ $2 \mathrm{H}), 8.61(\mathrm{~d}, 1 \mathrm{H}, J=4.8 \mathrm{~Hz}), 8.97(\mathrm{~d}, 1 \mathrm{H}, J=0.9 \mathrm{~Hz}) ;{ }^{13} \mathrm{C} \mathrm{NMR}\left(\mathrm{CDCl}_{3}\right)$ $\delta 91.0(\mathrm{C}), 122.3(\mathrm{CH}), 128.9(2 \mathrm{CH}), 130.2(2 \mathrm{CH}), 134.0(\mathrm{C}), 134.4(\mathrm{CH})$, $148.6(\mathrm{CH}), \quad 151.3 \quad(\mathrm{C}), \quad 157.7 \quad(\mathrm{CH}), 194.7 \quad(\mathrm{C}) .4$ 4-Benzoyl-3,5 diiodopyridine $\left(\mathbf{2} \boldsymbol{h}^{\text {g }}\right)^{[8]}$ was also isolated in $10 \%$ yield $(43.5 \mathrm{mg})$ as a yellowish powder: $\mathrm{mp} 148{ }^{\circ} \mathrm{C}$; IR (ATR): 683, 704, 728, 796, 934, 1037, $1174,1202,1270,1314,1389,1450,1499,1580,1595,1672,3059 \mathrm{~cm}$ ${ }^{1} ;{ }^{1} \mathrm{H}$ NMR $\left(\mathrm{CDCl}_{3}\right) \delta 7.52(\mathrm{td}, 2 \mathrm{H}, J=7.7$ and $0.9 \mathrm{~Hz}), 7.68(\mathrm{tt}, 1 \mathrm{H}, J=$ 7.5 and $1.7 \mathrm{~Hz}), 7.79-7.83(\mathrm{~m}, 2 \mathrm{H}), 8.91(\mathrm{~s}, 2 \mathrm{H}) ;{ }^{13} \mathrm{C} \mathrm{NMR}\left(\mathrm{CDCl}_{3}\right) \delta 90.7$ $(2 \mathrm{C}), 129.5(2 \mathrm{CH}), 130.2(2 \mathrm{CH}), 132.3(\mathrm{C}), 135.0(\mathrm{CH}), 155.4(\mathrm{C}), 156.3$ $(2 \mathrm{CH}), 194.8(\mathrm{C})$

3-Benzoyl-4-iodopyridine (2i). ${ }^{[8]}$ The general procedure 2 using 3benzoylpyridine $(1 \mathrm{i}, 0.18 \mathrm{~g})$, but performed at $-70{ }^{\circ} \mathrm{C}$ instead of $-55^{\circ} \mathrm{C}$, gave 2i (eluent: heptane-AcOEt $80: 20)$ in $37 \%$ yield $(0.11 \mathrm{~g})$ as a yellow powder: $\mathrm{mp} 136-138{ }^{\circ} \mathrm{C}$; IR (ATR): $656,705,731,918,938,1156,1259$, $1290,1317,1393,1449,1538,1558,1580,1667,2928,3063 \mathrm{~cm}^{-1} ;{ }^{1} \mathrm{H}$ $\operatorname{NMR}\left(\mathrm{CDCl}_{3}\right) \delta 7.46-7.53(\mathrm{~m}, 2 \mathrm{H}), 7.65(\mathrm{tt}, 1 \mathrm{H}, J=7.4$ and $2.7 \mathrm{~Hz}), 7.78-$ $7.84(\mathrm{~m}, 2 \mathrm{H}), 7.91(\mathrm{~d}, 1 \mathrm{H}, J=5.4 \mathrm{~Hz}), 8.31(\mathrm{~d}, 1 \mathrm{H}, J=5.4 \mathrm{~Hz}), 8.45(\mathrm{~s}$ $1 \mathrm{H}) ;{ }^{13} \mathrm{C}$ NMR $\left(\mathrm{CDCl}_{3}\right) \delta 104.4(\mathrm{C}), 129.0(2 \mathrm{CH}), 130.5(2 \mathrm{CH}), 134.4$ $(\mathrm{CH}), 134.9(\mathrm{CH}), 135.4(\mathrm{C}), 140.5(\mathrm{C}), 148.2(\mathrm{CH}), 150.7(\mathrm{CH}), 195.1$ (C).

3-Benzoyl-2-fluoro-4-iodopyridine (2j). ${ }^{[8]}$ The general procedure 2 using 3-benzoyl-2-fluoropyridine (1j, $0.20 \mathrm{~g})$ gave $\mathbf{2 j}$ (eluent: heptane-AcOEt $80: 20)$ in $63 \%$ yield $(0.21 \mathrm{~g})$ as a yellowish powder: $\mathrm{mp} 144^{\circ} \mathrm{C}$; IR (ATR): $660,684,827,877,926,1171,1230,1271,1316,1391,1442,1449$, $1539,1574,1669,3084 \mathrm{~cm}^{-1} ;{ }^{1} \mathrm{H}$ NMR $\left(\mathrm{CDCl}_{3}\right) \delta 7.46-7.53(\mathrm{~m}, 2 \mathrm{H}), 7.65$ (tt, $1 \mathrm{H}, J=7.4$ and $1.4 \mathrm{~Hz}$ ), 7.75 (dd, $1 \mathrm{H}, J=5.4$ and $1.1 \mathrm{~Hz}$ ), 7.79-7.83 $(\mathrm{m}, 2 \mathrm{H}), 7.97(\mathrm{dd}, 1 \mathrm{H}, J=5.1$ and $0.9 \mathrm{~Hz}) ;{ }^{13} \mathrm{C} \mathrm{NMR}\left(\mathrm{CDCl}_{3}\right) \delta 107.3(\mathrm{~d}$, C, $J=3.6 \mathrm{~Hz}), 127.9(\mathrm{~d}, \mathrm{C}, J=36 \mathrm{~Hz}), 129.2(2 \mathrm{CH}), 129.9(2 \mathrm{CH}), 132.3$ (d, $\mathrm{CH}, J=4.5 \mathrm{~Hz}), 134.8(\mathrm{C}), 134.8(\mathrm{CH}), 148.4(\mathrm{~d}, \mathrm{CH}, J=15 \mathrm{~Hz})$, $158.8(\mathrm{~d}, \mathrm{C}, J=241 \mathrm{~Hz}), 191.6(\mathrm{~d}, \mathrm{C}, J=3.5 \mathrm{~Hz})$.

3-Benzoyl-2-chloro-4-iodopyridine (2k). ${ }^{[53]}$ The general procedure 2 using 3-benzoyl-2-chloropyridine (1k, $0.22 \mathrm{~g}$ ) gave $\mathbf{2 k}$ (eluent: heptane-AcOEt $80: 20)$ in $73 \%$ yield $(0.25 \mathrm{~g})$ as a yellow powder: $\mathrm{mp} 130-132{ }^{\circ} \mathrm{C}$; IR (ATR): 657, 684, 725, 799, 827, 923, 1162, 1195, 1217, 1266, 1313, $1360,1428,1449,1528,1547,1581,1595,1668,2927,3062 \mathrm{~cm}^{-1} ;{ }^{1} \mathrm{H}$ $\operatorname{NMR}\left(\mathrm{CDCl}_{3}\right) \delta$ 7.47-7.54 (m, 2H), $7.65(\mathrm{tt}, 1 \mathrm{H}, J=7.4$ and $1.4 \mathrm{~Hz}), 7.79$ $7.84(\mathrm{~m}, 3 \mathrm{H}), 8.11(\mathrm{~d}, 1 \mathrm{H}, \mathrm{J}=5.4 \mathrm{~Hz}) ;{ }^{13} \mathrm{C} \mathrm{NMR}\left(\mathrm{CDCl}_{3}\right) \delta 105.3(\mathrm{C})$, $129.3(2 \mathrm{CH}), 129.9(2 \mathrm{CH}), 133.2(\mathrm{CH}), 134.0(\mathrm{C}), 134.8(\mathrm{CH}), 140.0(\mathrm{C})$, 146.9 (C), $149.8(\mathrm{CH}), 193.1(\mathrm{C})$.

2-Chloro-3-(2-chlorobenzoyl)-4-iodopyridine (2I). ${ }^{[8]}$ The general procedure 2 using 2-chloro-3-(2-chlorobenzoyl)pyridine (11, $0.25 \mathrm{~g})$ gave 2I (eluent: heptane-AcOEt $80: 20)$ in $78 \%$ yield $(0.29 \mathrm{~g})$ as a yellowish powder: $\mathrm{mp} 112-114{ }^{\circ} \mathrm{C}$; IR (ATR): $682,732,745,761,789,829,923$, $1054,1162,1196,1214,1252,1282,1359,1429,1466,1529,1546$ 1586, 1667, 1683, $3066 \mathrm{~cm}^{-1} ;{ }^{1} \mathrm{H}$ NMR $\left(\mathrm{CDCl}_{3}\right) \delta 7.38$ (ddd, $1 \mathrm{H}, J=7.8$, 6.6 and $1.8 \mathrm{~Hz}), 7.47-7.56(\mathrm{~m}, 2 \mathrm{H}), 7.78(\mathrm{~d}, 1 \mathrm{H}, J=5.1 \mathrm{~Hz}), 7.80$ (ddd, $1 \mathrm{H}, J=8.1,1.8$ and $0.6 \mathrm{~Hz}), 8.07(\mathrm{~d}, 1 \mathrm{H}, J=5.1 \mathrm{~Hz}) ;{ }^{13} \mathrm{C} \mathrm{NMR}\left(\mathrm{CDCl}_{3}\right) \delta$ $105.4(\mathrm{C}), 127.3(\mathrm{CH}), 132.0(\mathrm{CH}), 132.9(\mathrm{CH}), 133.2(\mathrm{C}), 133.5(\mathrm{CH})$, $134.5(\mathrm{CH}), 134.7(\mathrm{C}), 140.8(\mathrm{C}), 146.9(\mathrm{C}), 149.7(\mathrm{CH}), 191.4(\mathrm{C})$.

2-Chloro-4-iodo-3-(2-methoxybenzoyl)pyridine $(2 m){ }^{[8]}$ The general procedure 2 using 2-chloro-3-(2-methoxybenzoyl)pyridine $(1 \mathrm{~m}, 0.25 \mathrm{~g})$ gave $\mathbf{2 m}$ (eluent: heptane-AcOEt $70: 30)$ in $70 \%$ yield $(0.26 \mathrm{~g})$ as a yellow powder: mp $162-164^{\circ} \mathrm{C}$; IR (ATR): 693, 712, 747, 786, 835, 925, 1014 $1045,1090,1114,1160,1177,1199,1215,1251,1294,1366,1434$, $1465,1482,1532,1550,1575,1595,1651,1940,2840,2944 \mathrm{~cm}^{-1} ;{ }^{1} \mathrm{H}$ $\operatorname{NMR}\left(\mathrm{CDCl}_{3}\right) \delta 3.62(\mathrm{~s}, 3 \mathrm{H}), 6.95(\mathrm{dd}, 1 \mathrm{H}, J=8.4$ and $0.9 \mathrm{~Hz}$ ), 7.11 (ddd, $1 \mathrm{H}, J=8.1,7.2$ and $0.9 \mathrm{~Hz}$ ), 7.60 (ddd, $1 \mathrm{H}, J=9.0,7.2$ and $0.9 \mathrm{~Hz}), 7.74$ $(\mathrm{d}, 1 \mathrm{H}, J=5.1 \mathrm{~Hz}$ ), $8.01(\mathrm{~d}, 1 \mathrm{H}, J=5.4 \mathrm{~Hz}$ ), 8.06 (dd, $1 \mathrm{H}, J=7.8$ and 1.8
$\mathrm{Hz}) ;{ }^{13} \mathrm{C} \mathrm{NMR}\left(\mathrm{CDCl}_{3}\right) \delta 56.0\left(\mathrm{CH}_{3}\right), 103.6(\mathrm{C}), 112.3(\mathrm{CH}), 121.3(\mathrm{CH})$ $123.7(\mathrm{C}), 132.1(\mathrm{CH}), 132.8(\mathrm{CH}), 136.4(\mathrm{CH}), 143.5(\mathrm{C}), 145.9(\mathrm{C})$, $148.3(\mathrm{CH}), 160.2(\mathrm{C}), 191.3(\mathrm{C})$.

2-Chloro-3-cinnamoyl-4-iodopyridine $(2 n){ }^{[8]}$ The general procedure 2 using 2-chloro-3-cinnamoylpyridine (1n, $0.24 \mathrm{~g})$ gave $\mathbf{2 n}$ (eluent: heptane-AcOEt $80: 20)$ in $27 \%$ yield $(0.10 \mathrm{~g})$ as a yellow powder: $\mathrm{mp} 118$ $120^{\circ} \mathrm{C}$; IR (ATR): $680,700,733,748,765,975,1037,1110,1138,1198$ $1269,1330,1363,1429,1449,1528,1548,1575,1595,1619,1649$, 2925, $3063 \mathrm{~cm}^{-1} ;{ }^{1} \mathrm{H}$ NMR $\left(\mathrm{CDCl}_{3}\right) \delta 6.95(\mathrm{~d}, 1 \mathrm{H}, J=16 \mathrm{~Hz}), 7.32(\mathrm{~d}, 1 \mathrm{H}$, $J=16 \mathrm{~Hz}), 7.38-7.49(\mathrm{~m}, 3 \mathrm{H}), 7.55-7.59(\mathrm{~m}, 2 \mathrm{H}), 7.80(\mathrm{~d}, 1 \mathrm{H}, J=5.1 \mathrm{~Hz})$, $8.10(\mathrm{~d}, 1 \mathrm{H}, J=5.1 \mathrm{~Hz}) ;{ }^{13} \mathrm{C}$ NMR $\left(\mathrm{CDCl}_{3}\right) \delta 105.5(\mathrm{C}), 124.9(\mathrm{CH}), 129.0$ $(2 \mathrm{CH}), 129.3(2 \mathrm{CH}), 131.7(\mathrm{CH}), 133.4(\mathrm{CH}), 134.0(\mathrm{C}), 140.2(\mathrm{C}), 146.9$ (C), $148.5(\mathrm{CH}), 149.8(\mathrm{CH}), 193.2(\mathrm{C})$.

3-Benzoyl-4-iodo-2-methoxypyridine (2o) ${ }^{[8]}$ The general procedure 2 using 3-benzoyl-2-methoxypyridine $(\mathbf{1 0}, 0.21 \mathrm{~g})$ gave $\mathbf{2 0}$ (eluent: heptane-AcOEt $80: 20)$ in $88 \%$ yield $(0.30 \mathrm{~g})$ as a yellow powder: $\mathrm{mp} 144-$ $146{ }^{\circ} \mathrm{C}$; IR (ATR): 660, 685, 707, 730, 803, 847, 926, 1015, 1234, 1274 , $1301,1313,1372,1455,1552,1668,2948 \mathrm{~cm}^{-1} ;{ }^{1} \mathrm{H}$ NMR $\left(\mathrm{CDCl}_{3}\right) \delta 3.82$ (s, 3H), $7.39(\mathrm{~d}, 1 \mathrm{H}, J=5.4 \mathrm{~Hz}), 7.45(\mathrm{tt}, 2 \mathrm{H}, J=7.5$ and $1.7 \mathrm{~Hz}), 7.59$ (tt, $1 \mathrm{H}, J=7.4$ and $1.4 \mathrm{~Hz}), 7.78-7.83(\mathrm{~m}, 2 \mathrm{H}), 7.86(\mathrm{~d}, 1 \mathrm{H}, J=5.4 \mathrm{~Hz}) ;{ }^{13} \mathrm{C}$ NMR $\left(\mathrm{CDCl}_{3}\right) \delta 54.2\left(\mathrm{CH}_{3}\right), 104.9(\mathrm{C}), 127.0(\mathrm{CH}), 128.6(\mathrm{C}), 128.9$ $(2 \mathrm{CH}), 129.7(2 \mathrm{CH}), 134.1(\mathrm{CH}), 135.1(\mathrm{C}), 147.5(\mathrm{CH}), 160.5(\mathrm{C}), 194.5$ (C)

2-Benzoyl-5-iodothiophene (2p). The general procedure 2 using 2benzoylthiophene (1p, $0.19 \mathrm{~g}$ ) gave 2p (eluent: heptane-AcOEt 80:20) in $80 \%$ yield $(0.25 \mathrm{~g})$ as a whitish powder: $\mathrm{mp} 129-131{ }^{\circ} \mathrm{C}$ (lit. ${ }^{[54]} 132$ $133^{\circ} \mathrm{C}$ ); IR (ATR): 685, 696, 714, 783, 812, 857, 927, 952, 1066, 1138 $1213,1297,1316,1378,1405,1443,1516,1575,1595,1613,3054$ $3228 \mathrm{~cm}^{-1} ;{ }^{1} \mathrm{H}$ NMR $\left(\mathrm{CDCl}_{3}\right) \delta 7.27(\mathrm{~d}, 1 \mathrm{H}, J=3.9 \mathrm{~Hz}), 7.33(\mathrm{~d}, 1 \mathrm{H}, J=$ $3.9 \mathrm{~Hz}), 7.46-7.53(\mathrm{~m}, 2 \mathrm{H}), 7.57-7.63(\mathrm{~m}, 1 \mathrm{H}), 7.80-7.85(\mathrm{~m}, 2 \mathrm{H}) ;{ }^{13} \mathrm{C}$ NMR $\left(\mathrm{CDCl}_{3}\right) \delta 86.0(\mathrm{C}), 128.6(2 \mathrm{CH}), 129.1(2 \mathrm{CH}), 132.6(\mathrm{CH}), 135.7$ $(\mathrm{CH}), 137.6(\mathrm{C}), 138.1(\mathrm{CH}), 149.5(\mathrm{C}), 186.7(\mathrm{C})$. These data are as described previously. ${ }^{[54]}$

1-(2-Pyridyl)-9-xanthone (3a).$^{[8]}$ To a stirred mixture of 9-xanthone (1a, $0.19 \mathrm{~g}, 1.0 \mathrm{mmol}$ ) and $\mathrm{ZnCl}_{2} \cdot \operatorname{TMEDA}(0.25 \mathrm{~g}, 1.0 \mathrm{mmol})$ in THF $(3 \mathrm{~mL})$ at $-55^{\circ} \mathrm{C}$ was added dropwise a solution of LiTMP (prepared by adding BuLi (about 1.6 M hexanes solution, $1.5 \mathrm{mmol}$ ) to a stirred, cooled $\left(0^{\circ} \mathrm{C}\right)$ solution of 2,2,6,6-tetramethylpiperidine $(0.25 \mathrm{~mL}, 1.5 \mathrm{mmol})$ in THF (3 $\mathrm{mL}$ ) and stirring for $5 \mathrm{~min}$ ) cooled at $-55^{\circ} \mathrm{C}$. After $15 \mathrm{~min}$ at $-55^{\circ} \mathrm{C}$, 2chloropyridine $(0.55 \mathrm{~g}, 4.8 \mathrm{mmol})$, palladium(II) chloride ( $14 \mathrm{mg}, 80 \mu \mathrm{mol})$ and $1,1^{\prime}$-diphenylphosphinoferrocene $(44 \mathrm{mg}, 80 \mu \mathrm{mol}$ ) were added to the reaction mixture, and the latter was heated at THF reflux for $16 \mathrm{~h}$. After addition of water $(0.5 \mathrm{~mL})$ and EtOAc $(50 \mathrm{~mL})$, and drying over anhydrous $\mathrm{Na}_{2} \mathrm{SO}_{4}$, the solvent was evaporated under reduced pressure. The coupled product was isolated by purification by chromatography over silica gel (eluent: heptane-AcOEt 60:40 to $50: 50$ ) to afford $\mathbf{3 a}$ in $76 \%$ yield $(0.21 \mathrm{~g})$ as a light grey powder: $\mathrm{mp} 183-184{ }^{\circ} \mathrm{C}$; IR (ATR): 631,672 , $725,750,760,786,925,1235,1301,1333,1349,1431,1463,1488$ $1569,1589,1599,1615,1652,2962,3065 \mathrm{~cm}^{-1} ;{ }^{1} \mathrm{H}$ NMR $\left(\mathrm{CDCl}_{3}\right) \delta 7.28-$ $7.35(\mathrm{~m}, 3 \mathrm{H}), 7.40(\mathrm{~d}, 1 \mathrm{H}, J=7.8 \mathrm{~Hz}), 7.48(\mathrm{~d}, 1 \mathrm{H}, J=8.4 \mathrm{~Hz}), 7.58(\mathrm{dd}$, $1 \mathrm{H}, J=8.4$ and $0.7 \mathrm{~Hz}$ ), $7.69(\mathrm{td}, 1 \mathrm{H}, J=7.8$ and $1.5 \mathrm{~Hz}), 7.74(\mathrm{t}, 1 \mathrm{H}, J=$ $7.9 \mathrm{~Hz}$ ), $7.77(\mathrm{td}, 1 \mathrm{H}, J=7.7$ and $1.7 \mathrm{~Hz}), 8.16(\mathrm{dd}, 1 \mathrm{H}, J=8.0$ and 1.4 $\mathrm{Hz}), 8.69(\mathrm{~d}, 1 \mathrm{H}, J=4.6 \mathrm{~Hz}) ;{ }^{13} \mathrm{C} \mathrm{NMR}\left(\mathrm{CDCl}_{3}\right) \delta 117.7(\mathrm{CH}), 118.7(\mathrm{CH})$, $119.6(\mathrm{C}), 122.2(\mathrm{CH}), 122.7(\mathrm{C}), 123.7(\mathrm{CH}), 124.0(\mathrm{CH}), 126.5(\mathrm{CH})$, $127.0(\mathrm{CH}), 133.9(\mathrm{CH}), 134.8(\mathrm{CH}), 135.6(\mathrm{CH}), 142.7(\mathrm{C}), 148.9(\mathrm{CH})$, 155.6 (C), 157.1 (C), 159.9 (C), 176.9 (C).

5-Phenyl-1,3,4,6,9b-pentaazacyclopenta[a]naphthalene (3g1). The general procedure 4 using 3 -amino-1,2,4-triazole $(0.10 \mathrm{~g})$ gave $3 \mathrm{~g} 1$ (eluent: heptane-AcOEt 50:50) in 54\% yield $(0.13 \mathrm{~g})$ as a yellow powder: 
mp $198^{\circ} \mathrm{C}$; IR (ATR): 681, 827, 1306, 1355, 1451, 1547, 1598, $3059 \mathrm{~cm}$ ${ }^{1} ;{ }^{1} \mathrm{H} \mathrm{NMR}\left(\mathrm{CDCl}_{3}\right) \delta$ 7.52-7.56 (m, 3H), $7.88(\mathrm{dd}, 1 \mathrm{H}, J=8.6$ and $4.4 \mathrm{~Hz})$ 8.28-8.32 (m, 2H), $8.51(\mathrm{~m}, 1 \mathrm{H}), 8.80(\mathrm{dd}, 1 \mathrm{H}, J=8.6$ and $1.7 \mathrm{~Hz}), 9.03$ (dd, $1 \mathrm{H}, J=4.4$ and $1.7 \mathrm{~Hz}) ;{ }^{13} \mathrm{C} \operatorname{NMR}\left(\mathrm{CDCl}_{3}\right) \delta 123.8(\mathrm{CH}), 128.0(\mathrm{CH})$, $128.2(2 \mathrm{CH}), 131.1(\mathrm{CH}), 131.7(2 \mathrm{CH}), 133.4(\mathrm{C}), 134.3(\mathrm{C}), 135.7(\mathrm{C})$, $148.9(\mathrm{CH}), 152.3(\mathrm{C}), 155.4(\mathrm{CH}), 164.5(\mathrm{C})$.

5-Phenyl-1,4,6,9b-tetraaza-cyclopenta[a]naphthalene (3g2). The general procedure 4 using 3-aminopyrazole $(0.10 \mathrm{~g})$ gave $3 \mathrm{~g} 2$ (eluent: heptaneAcOEt $50: 50$ ) in $18 \%$ yield $\left(44 \mathrm{mg}\right.$ ) as a yellow powder: $\mathrm{mp} 180^{\circ} \mathrm{C}$; IR (ATR): 690, 742, 795, 811, 909, 1297, 1350, 1396, 1439, 1450, 1526, 1549, 1596, $3061 \mathrm{~cm}^{-1} ;{ }^{1} \mathrm{H}$ NMR $\left(\mathrm{CDCl}_{3}\right) \delta 6.88(\mathrm{~d}, 1 \mathrm{H}, J=2.1 \mathrm{~Hz}), 7.53$ $7.59(\mathrm{~m}, 3 \mathrm{H}), 7.79(\mathrm{dd}, 1 \mathrm{H}, J=8.6$ and $1.4 \mathrm{~Hz}), 8.14-8.18(\mathrm{~m}, 3 \mathrm{H}), 8.86$ (dd, $1 \mathrm{H}, J=8.6$ and $1.7 \mathrm{~Hz}$ ), $8.92(\mathrm{dd}, 1 \mathrm{H}, J=4.4$ and $1.7 \mathrm{~Hz}) ;{ }^{13} \mathrm{C} \mathrm{NMR}$ $\left(\mathrm{CDCl}_{3}\right) \delta 100.6(\mathrm{CH}), 123.3(\mathrm{CH}), 127.3(\mathrm{CH}), 128.3(2 \mathrm{CH}), 130.2(\mathrm{CH})$, $131.0(2 \mathrm{CH}), 134.0(\mathrm{C}), 134.2(\mathrm{C}), 136.7(\mathrm{C}), 144.3(\mathrm{CH}), 145.1(\mathrm{C})$, $147.6(\mathrm{CH}), 159.0(\mathrm{C})$

5-Phenyl-4,6,7,11b-tetraazabenzo[c]fluorene (3g3). The general procedure 4 using 2-aminobenzimidazole $(0.16 \mathrm{~g})$ gave $\mathbf{3 g} 3$ (eluent: $\mathrm{CH}_{2} \mathrm{Cl}_{2}$-AcOEt $\left.80: 20\right)$ in $50 \%$ yield $(0.15 \mathrm{~g})$ as a yellow powder: $\mathrm{mp}$ $175{ }^{\circ} \mathrm{C}$; IR (ATR): $684,736,1194,1351,1390,1448,1538,1590 \mathrm{~cm}^{-1}$; ${ }^{1} \mathrm{H}$ NMR $\left(\mathrm{CDCl}_{3}\right) \delta$ 7.41-7.52 (m, 2H), 7.53-7.59 (m, 3H), $7.83(\mathrm{dd}, 1 \mathrm{H}$, $=8.7$ and $1.5 \mathrm{~Hz}$ ), 8.00 (dd, $1 \mathrm{H}, J=8.1$ and $1.5 \mathrm{~Hz}$ ), $8.11(\mathrm{dd}, 1 \mathrm{H}, J=8.4$ and $1.2 \mathrm{~Hz}), 8.34-8.38(\mathrm{~m}, 2 \mathrm{H}), 8.75(\mathrm{dd}, 1 \mathrm{H}, J=8.6$ and $1.4 \mathrm{~Hz}), 8.89$ (dd, $1 \mathrm{H}, J=4.2$ and $1.2 \mathrm{~Hz}) ;{ }^{13} \mathrm{C}$ NMR $\left(\mathrm{CDCl}_{3}\right) \delta 113.2(\mathrm{CH}), 121.5(\mathrm{CH})$, $122.6(\mathrm{CH}), 123.7(\mathrm{CH}), 125.2(\mathrm{CH}), 127.1(\mathrm{CH}), 128.1(2 \mathrm{CH}), 129.4(\mathrm{C})$, $130.9(\mathrm{CH}), 131.7(2 \mathrm{CH}), 134.4(\mathrm{C}), 135.1(\mathrm{C}), 136.2(\mathrm{C}), 144.7(\mathrm{C})$, $146.1(\mathrm{CH}), 149.0(\mathrm{C}), 164.1(\mathrm{C})$.

2-Amino-4-phenylpyrido[2,3-d]pyrimidine (4j). The general procedure 5 , but without Cul, using 3-benzoyl-2-fluoropyridine (1j, $0.20 \mathrm{~g})$ gave $4 \mathrm{j}$ (eluent: AcOEt-MeOH-NEt $t_{3}$ 96:2:2) in $94 \%$ yield $(0.21 \mathrm{~g})$ as a yellowish powder: $\mathrm{mp} 192-194{ }^{\circ} \mathrm{C}$; IR (ATR): $709,730,769,786,952,1127,1185$, $1205,1260,1339,1372,1412,1447,1468,1548,1566,1595,1621$, 2219, 3166, 3283, $3403 \mathrm{~cm}^{-1} ;{ }^{1} \mathrm{H}$ NMR $\left(\mathrm{CDCl}_{3}\right) \delta 6.15(\mathrm{br} \mathrm{s}, 2 \mathrm{H}), 7.13(\mathrm{dd}$ $1 \mathrm{H}, J=8.1$ and $4.4 \mathrm{~Hz}), 7.52-7.56(\mathrm{~m}, 3 \mathrm{H}), 7.64-7.68(\mathrm{~m}, 2 \mathrm{H}), 8.13(\mathrm{dd}$, $1 \mathrm{H}, J=8.1$ and $2.1 \mathrm{~Hz}), 8.94(\mathrm{dd}, 1 \mathrm{H}, J=4.2$ and $2.1 \mathrm{~Hz}) ;{ }^{13} \mathrm{C}$ NMR $\left(\mathrm{CDCl}_{3}\right) \delta 112.8(\mathrm{C}), 118.7(\mathrm{CH}), 128.8(2 \mathrm{CH}), 129.6(2 \mathrm{CH}), 130.4(\mathrm{CH})$, $136.3(\mathrm{C}), 136.8(\mathrm{CH}), 157.5(\mathrm{CH}), 161.1(\mathrm{C}), 162.1(\mathrm{C}), 172.3(\mathrm{C})$.

2-Amino-4-phenylpyrido[3,2-d]pyrimidine $(\mathbf{4 g}){ }^{[8]}$ The general procedure 5 using 2-benzoyl-3-iodopyridine $(\mathbf{2 g}, 0.31 \mathrm{~g})$ gave $\mathbf{4 g}$ (eluent: heptaneAcOEt-NEt $\left.{ }_{3} 80: 18: 2\right)$ in $77 \%$ yield $(0.17 \mathrm{~g})$ as a yellowish powder: $\mathrm{mp}$ 140-142 ${ }^{\circ} \mathrm{C}$; IR (ATR): 695, 739, 765, 804, 1124, 1231, 1344, 1376, 1422 $1458,1548,1583,1601,1628,3060,3171,3313,3477 \mathrm{~cm}^{-1} ;{ }^{1} \mathrm{H}$ NMR $\left(\mathrm{CDCl}_{3}\right) \delta 5.67(\mathrm{br} \mathrm{s}, 2 \mathrm{H}), 7.51-7.58(\mathrm{~m}, 4 \mathrm{H}), 7.91(\mathrm{dd}, 1 \mathrm{H}, J=8.7$ and $1.7 \mathrm{~Hz}), 8.16-8.20(\mathrm{~m}, 2 \mathrm{H}), 8.71(\mathrm{dd}, 1 \mathrm{H}, J=3.9$ and $1.7 \mathrm{~Hz}) ;{ }^{13} \mathrm{C} \mathrm{NMR}$ $\left(\mathrm{CDCl}_{3}\right) \delta 127.9(\mathrm{CH}), 128.2(2 \mathrm{CH}), 130.6(\mathrm{CH}), 131.2(2 \mathrm{CH}), 133.8(\mathrm{CH})$ $135.5(\mathrm{C}), 136.2(\mathrm{C}), 146.9(\mathrm{CH}), 149.5(\mathrm{C}), 159.9(\mathrm{C}), 169.4(\mathrm{C})$.

2-Amino-4-phenylpyrido[3,4-d]pyrimidine (4h). The general procedure 5 using 4-benzoyl-3-iodopyridine $(\mathbf{2 h}, 0.31 \mathrm{~g})$ gave $\mathbf{4 h}$ (eluent: heptaneAcOEt-NEt $\left._{3} 70: 28: 2\right)$ in $61 \%$ yield $(0.14 \mathrm{~g})$ as a yellow powder: $\mathrm{mp} 242$ $244{ }^{\circ} \mathrm{C}$; IR (ATR): 673, 704, 764, 779, 808, 1026, 1155, 1227, 1378 $1415,1488,1545,1567,1584,1660,3082,3301 \mathrm{~cm}^{-1} ;{ }^{1} \mathrm{H} \mathrm{NMR}\left(\mathrm{CDCl}_{3}\right)$ $\delta 5.46(\mathrm{br} \mathrm{s}, 2 \mathrm{H}), 7.57-7.60(\mathrm{~m}, 3 \mathrm{H}), 7.66(\mathrm{dd}, 1 \mathrm{H}, J=5.7$ and $1.1 \mathrm{~Hz})$, 7.72-7.77 (m, 2H), $8.39(\mathrm{~d}, 1 \mathrm{H}, J=5.7 \mathrm{~Hz}), 9.14(\mathrm{~s}, 1 \mathrm{H}) ;{ }^{13} \mathrm{C}$ NMR $\left(\mathrm{CDCl}_{3}\right) \delta 118.7(\mathrm{CH}), 121.1(\mathrm{C}), 129.0(2 \mathrm{CH}), 129.6(2 \mathrm{CH}), 130.7(\mathrm{CH})$, $136.1(\mathrm{C}), 141.3(\mathrm{CH}), 147.9(\mathrm{C}), 151.7(\mathrm{CH}), 160.5(\mathrm{C}), 170.6(\mathrm{C})$.

2-Amino-4-phenylpyrido[4,3-d]pyrimidine (4i). The general procedure 5 using 3-benzoyl-4-iodopyridine (2i, $0.31 \mathrm{~g})$ gave $4 \mathbf{i}$ (eluent: heptane-
AcOEt-NEt $\left.{ }_{3} 70: 28: 2\right)$ in $68 \%$ yield $(0.15 \mathrm{~g})$ as a yellowish powder: $\mathrm{mp}$ 112-114 ${ }^{\circ} \mathrm{C}$; IR (ATR): 703, 765, 834, 952, 1030, 1042, 1179, 1272, 1356, 1384, 1413, 1442, 1456, 1507, 1548, 1602, 1637, 3167, $3309 \mathrm{~cm}^{-1} ;{ }^{1} \mathrm{H}$ $\operatorname{NMR}\left(\mathrm{CDCl}_{3}\right) \delta 6.03(\mathrm{br} \mathrm{s}, 2 \mathrm{H}), 7.38(\mathrm{dd}, 1 \mathrm{H}, J=6.0$ and $0.9 \mathrm{~Hz}), 7.53-$ $7.60(\mathrm{~m}, 3 \mathrm{H}), 7.71-7.75(\mathrm{~m}, 2 \mathrm{H}), 8.60(\mathrm{~d}, 1 \mathrm{H}, J=6.0 \mathrm{~Hz}), 9.12(\mathrm{~s}, 1 \mathrm{H})$; ${ }^{13} \mathrm{C} \mathrm{NMR}\left(\mathrm{CDCl}_{3}\right) \delta 115.2(\mathrm{C}), 119.0(\mathrm{CH}), 128.9(2 \mathrm{CH}), 129.8(2 \mathrm{CH})$, $130.8(\mathrm{CH}), 135.7(\mathrm{C}), 150.8(\mathrm{CH}), 152.3(\mathrm{CH}), 156.7(\mathrm{C}), 161.7(\mathrm{C})$, $172.1(\mathrm{C})$

2-Amino-5-methoxy-4-phenylpyrido[4,3-d]pyrimidine (40). The general procedure 5 using 3-benzoyl-4-iodo-2-methoxypyridine $(20,0.34 \mathrm{~g})$ gave 4o (eluent: heptane-AcOEt-NEt $\left.{ }_{3} 80: 18: 2\right)$ in $65 \%$ yield $(0.16 \mathrm{~g})$ as a white powder: mp $146-148{ }^{\circ} \mathrm{C}$; IR (ATR): 702, 837, 913, 980, 1104, 1131, 1290 $1321,1367,1435,1447,1540,1559,1600,1634,2949,3176,3312 \mathrm{~cm}$ 1; ${ }^{1} \mathrm{H}$ NMR $\left(\mathrm{CDCl}_{3}\right) \delta 3.69(\mathrm{~s}, 3 \mathrm{H}), 5.89(\mathrm{br} \mathrm{s}, 2 \mathrm{H}), 6.98(\mathrm{~d}, 1 \mathrm{H}, J=6.0 \mathrm{~Hz})$ 7.40-7.50 (m, 5H), $8.13(\mathrm{~d}, 1 \mathrm{H}, J=6.0 \mathrm{~Hz}) ;{ }^{13} \mathrm{C} \mathrm{NMR}\left(\mathrm{CDCl}_{3}\right) \delta 53.4$ $\left(\mathrm{CH}_{3}\right), 105.6(\mathrm{C}), 113.9(\mathrm{CH}), 127.6(2 \mathrm{CH}), 128.3(2 \mathrm{CH}), 129.1(\mathrm{CH})$, $140.4(\mathrm{C}), 148.4(\mathrm{CH}), 160.3(\mathrm{C}), 161.3(\mathrm{C}), 161.7(\mathrm{C}), 171.1(\mathrm{C})$

2-Aminobenzopyrano[4,3,2-de]quinazoline (4a). The general procedure 5 using 1-iodoxanthone $(\mathbf{2 a}, 0.32 \mathrm{~g})$ gave $\mathbf{4 a}$ (eluent: AcOEt-heptane-NEt $70: 28: 2)$ in $86 \%$ yield $(0.20 \mathrm{~g})$ as a yellow powder: $\mathrm{mp} 236-238{ }^{\circ} \mathrm{C}$; IR (ATR): 717, 758, 816, 1053, 1072, 1249, 1259, 1324, 1348, 1435, 1453, $1490,1561,1596,1615,1640,1667,2854,2924,3173,3302,3481 \mathrm{~cm}$ 1; ${ }^{1} \mathrm{H}$ NMR $\left(\mathrm{CDCl}_{3}\right) \delta 5.21(\mathrm{br} \mathrm{s}, 2 \mathrm{H}), 6.93(\mathrm{dd}, 1 \mathrm{H}, J=8.1$ and $0.8 \mathrm{~Hz})$, $7.18(\mathrm{dd}, 1 \mathrm{H}, J=8.4$ and $0.8 \mathrm{~Hz}$ ), 7.28-7.35 (m, 2H), 7.60 (ddd, $1 \mathrm{H}, J=$ 8.7, 7.2 and $1.8 \mathrm{~Hz}$ ), 7.69 (dd, $1 \mathrm{H}, J=8.4$ and $8.1 \mathrm{~Hz}$ ), 8.41 (ddd, $1 \mathrm{H}, J=$ 7.8, 1.8 and $0.6 \mathrm{~Hz}) ;{ }^{13} \mathrm{C}$ NMR $\left(\mathrm{CDCl}_{3}\right) \delta 105.9(\mathrm{CH}), 109.3(\mathrm{C}), 116.6$ $(\mathrm{CH}), 117.7(\mathrm{CH}), 119.2(\mathrm{C}), 124.1(\mathrm{CH}), 125.0(\mathrm{CH}), 134.0(\mathrm{CH}), 135.4$ (CH), 152.1 (C), $152.2(\mathrm{C}), 155.5(\mathrm{C}), 157.9$ (C), 161.6 (C).

2-Aminobenzothiopyrano[4,3,2-de]quinazoline (4b). The general procedure 5 using 1-iodothioxanthone $(2 \mathrm{~b}, 0.34 \mathrm{~g})$ gave $4 \mathrm{~b}$ (eluent: AcOEt-heptane- $\left.\mathrm{NEt}_{3} 70: 28: 2\right)$ in $84 \%$ yield $(0.21 \mathrm{~g})$ as a yellow powder: $\mathrm{mp} 258-260^{\circ} \mathrm{C}$; IR (ATR): 714, 758, 772, 815, 986, 1081, 1205, 1237, $1268,1336,1417,1437,1466,1476,1549,1561,1602,1639,1666$ $1733,2853,2923,3167,3324 \mathrm{~cm}^{-1} ;{ }^{1} \mathrm{H}$ NMR $\left(\mathrm{CDCl}_{3}\right) \delta 5.13$ (br s, $\left.2 \mathrm{H}\right)$ 7.12 (dd, $1 \mathrm{H}, J=7.5$ and $0.9 \mathrm{~Hz}$ ), $7.27(\mathrm{dd}, 1 \mathrm{H}, J=8.6$ and $0.9 \mathrm{~Hz}$ ), 7.33 $7.40(\mathrm{~m}, 2 \mathrm{H}), 7.47(\mathrm{td}, 1 \mathrm{H}, J=6.6$ and $1.5 \mathrm{~Hz}), 7.55(\mathrm{dd}, 1 \mathrm{H}, J=8.4$ and $7.5 \mathrm{~Hz}$ ), $8.80(\mathrm{dd}, 1 \mathrm{H}, J=8.7$ and $1.5 \mathrm{~Hz}) ;{ }^{13} \mathrm{C} \mathrm{NMR}\left(\mathrm{CDCl}_{3}\right) \delta 115.2(\mathrm{C})$, $116.8(\mathrm{CH}), 120.7(\mathrm{CH}), 125.9(\mathrm{CH}), 126.5(\mathrm{CH}), 127.7(\mathrm{C}), 128.2(\mathrm{CH})$ $131.8(\mathrm{CH}), 133.2(\mathrm{C}), 133.4(\mathrm{CH}), 136.0(\mathrm{C}), 154.4(\mathrm{C}), 160.2(\mathrm{C}), 160.7$ (C).

2-Amino-7-oxa-1,3,6-triazabenz[de]anthracene (4d). The general procedure 5 using 4-iodo-1-azaxanthone $(\mathbf{2 d}, 0.32 \mathrm{~g})$ gave $4 \mathrm{~d}$ (eluent: AcOEt-heptane- $\left.\mathrm{NEt}_{3} \quad 80: 18: 2\right)$ in $83 \%$ yield $(0.20 \mathrm{~g})$ as a yellowish powder: $\mathrm{mp}>264^{\circ} \mathrm{C}$; IR (ATR): 750, 837, 939, 1077, 1127, 1202, 1242 $1291,1319,1378,1418,1447,1470,1515,1557,1583,1626,1670$, $3083,3284 \mathrm{~cm}^{-1}$; ${ }^{1} \mathrm{H}$ NMR $\left(\left(\mathrm{CD}_{3}\right)_{2} \mathrm{SO}\right) \delta 6.96(\mathrm{~d}, 1 \mathrm{H}, J=6.3 \mathrm{~Hz}), 7.45$ $7.51(\mathrm{~m}, 3 \mathrm{H}), 7.60(\mathrm{dd}, 1 \mathrm{H}, J=8.4$ and $1.2 \mathrm{~Hz}), 7.79$ (ddd, $1 \mathrm{H}, J=8.7$, 7.2 and $1.7 \mathrm{~Hz}), 6.24(\mathrm{~d}, 1 \mathrm{H}, J=6.0 \mathrm{~Hz}), 8.32(\mathrm{dd}, 1 \mathrm{H}, J=8.0$ and 1.7 $\mathrm{Hz}) ;{ }^{13} \mathrm{C}$ NMR $\left(\left(\mathrm{CD}_{3}\right)_{2} \mathrm{SO}\right) \delta 102.8(\mathrm{C}), 112.9(\mathrm{CH}), 118.2(\mathrm{CH}), 118.3(\mathrm{C})$, $124.1(\mathrm{CH}), 124.9(\mathrm{CH}), 134.6(\mathrm{CH}), 150.2(\mathrm{CH}), 154.5(\mathrm{C}), 158.1(\mathrm{C})$ $158.2(\mathrm{C}), 158.3(\mathrm{C}), 164.1(\mathrm{C})$

2-Amino-7-thia-1,3,6-triazabenz[de]anthracene (4e). The genera procedure 5 using 4-iodo-1-azathioxanthone $(2 \mathrm{e}, 0.34 \mathrm{~g})$ gave $4 \mathrm{e}$ (eluent: AcOEt-heptane- $\left.\mathrm{NEt}_{3} 70: 28: 2\right)$ in $88 \%$ yield $(0.22 \mathrm{~g})$ as a yellow powder mp 264-266 ${ }^{\circ} \mathrm{C}$; IR (ATR): 725, 763, 809, 834, 1009, 1038, 1081, 1156, $1181,1235,1260,1314,1373,1451,1538,1595,1662,2851,2922$ 2959, 3111, $3293 \mathrm{~cm}^{-1} ;{ }^{1} \mathrm{H}$ NMR $\left(\left(\mathrm{CD}_{3}\right)_{2} \mathrm{SO}\right) \delta 7.00(\mathrm{~d}, 1 \mathrm{H}, J=6.0 \mathrm{~Hz})$, $7.43(\mathrm{br} \mathrm{s}, 2 \mathrm{H}), 7.56$ (ddd, $1 \mathrm{H}, J=8.1,5.7$ and $3.0 \mathrm{~Hz}$ ), 7.68-7.71 (m, 2H), $8.31(\mathrm{~d}, 1 \mathrm{H}, J=6.0 \mathrm{~Hz}), 8.75(\mathrm{dt}, 1 \mathrm{H}, J=8.1$ and $1.1 \mathrm{~Hz}) ;{ }^{13} \mathrm{C} \mathrm{NMR}$ 
$\left(\left(\mathrm{CD}_{3}\right)_{2} \mathrm{SO}\right) \delta 111.2(\mathrm{C}), 114.6(\mathrm{CH}), 126.1(\mathrm{C}), 126.6(\mathrm{CH}), 127.0(\mathrm{CH})$, $127.3(\mathrm{CH}), 132.5(\mathrm{CH}), 135.5(\mathrm{C}), 150.0(\mathrm{CH}), 157.3(\mathrm{C}), 157.5(\mathrm{C})$ $160.3(\mathrm{C}), 162.9(\mathrm{C})$.

\section{Acknowledgements}

We thank the Ministère de l'Enseignement supérieur et de la Recherche scientifique Algérien (M.H.), the Centre National de la Recherche Scientifique (CNRS), the Institut Universitaire de France and Rennes Métropole (F.M.). We also thank the Cancéropôle Grand-Ouest (axis: Marine natural products in cancer treatment), GIS IBiSA (Infrastructures en Biologie Santé et Agronomie, France) and Biogenouest (Western France life science and environment core facility network) for supporting KISSf screening facility (Roscoff, France). We acknowledge FEDER founds (D8 VENTURE Bruker AXS diffractometer) and Thermofisher (generous gift of 2,2,6,6-tetramethylpiperidine). This research has been partly performed as part of the CNRS projet international de cooperation scientifique (PICS) project "Bimetallic synergy for the functionalization of heteroaromatics".

Keywords: ketones; pyrimidines; copper; C-N bond formation; $\mathrm{C}-\mathrm{H}$ acidity

[1] a) R. Romagnoli, P. G. Baraldi, M. D. Carrion, C. L. Cara, O. CruzLopez, M. Tolomeo, S. Grimaudo, A. Di Cristina, M. R. Pipitone, J. Balzarini, N. Zonta, A. Brancale, E. Hamel, Bioorg. Med. Chem. 2009 17, 6862-6871; b) W. Zhao, X. Feng, S. Ban, W. Lin, Q. Li, Bioorg Med. Chem. Lett. 2010, 20, 4132-4134; c) D. Shi, J. Li, B. Jiang, S Guo, H. Su, T. Wang, Bioorg. Med. Chem. Lett. 2012, 22, 2827-2832.

[2] P. Rajamalli, N. Senthilkumar, P. Gandeepan, P.-Y. Huang, M.-J. Huang, C.-Z. Ren-Wu, C.-Y. Yang, M.-J. Chiu, L.-K. Chu, H.-W. Lin, C.H. Cheng, J. Am. Chem. Soc. 2016, 138, 628-634.

[3] a) F. Monnier, M. Taillefer, Angew. Chem. Int. Ed. 2009, 48, 6954-6971; b) I. P. Beletskaya, A. V. Cheprakov, Organometallics 2012, 31, 7753-7808; c) P. Ruiz-Castillo, S. L. Buchwald, Chem. Rev. 2016, 116, 12564-12649.

[4] a) E. Dubost, S. Stiebing, T. Ferrary, T. Cailly, F. Fabis, V. Collot, Tetrahedron 2014, 70, 8413-8418; b) L. Gao, Y. Song, X. Zhang, S. Guo, X. Fan, Tetrahedron Lett. 2014, 55, 4997-5002; c) D. S. Baranov, D. S. Fadeev, Mendeleev Commun. 2016, 26, 174-176.

[5] a) A. Kedrov, C. Ziegler, D. J. Muller, J. Mol. Biol. 2006, 362, 925-932; b) C. M. Martínez-Viturro, D. Domínguez, J. Heterocycl. Chem. 2007, 44, 1035-1043; c) L. Wei, S. V. Malhotra, MedChemComm 2012, 3 , 1250-1257; d) M. Andaloussi, H. D. Lim, T. van der Meer, M. Sijm, C. B. M. Poulie, I. J. P. de Esch, R. Leurs, R. A. Smits, Bioorg. Med. Chem. Lett. 2013, 23, 2663-2670; e) S. Lin, F. Han, P. Liu, J. Tao, X. Zhong, X. Liu, C. Yi, H. Xu, Bioorg. Med. Chem. Lett. 2014, 24, 790-793.

[6] N. Schröder, J. Wencel-Delord, F. Glorius, J. Am. Chem. Soc. 2012, 134, 8298-8301.

[7] X. Sun, G. Shan, Y. Sun, Y. Rao, Angew. Chem., Int. Ed. 2013, 52, 4440-4444.

[8] M. Hedidi, W. Erb, F. Lassagne, Y. S. Halauko, O. A. Ivashkevich, V. E. Matulis, T. Roisnel, G. Bentabed-Ababsa, F. Mongin, RSC Adv. 2016, 6, 63185-63189

[9] a) R. R. Kadiyala, D. Tilly, E. Nagaradja, T. Roisnel, V. E. Matulis, O. A. Ivashkevich, Y. S. Halauko, F. Chevallier, P. C. Gros, F. Mongin, Chem Eur. J. 2013, 19, 7944-7960; b) All the calculations were performed using the B3LYP hybrid functional. The single point energies were obtained using the $6-311+G(d, p)$ basis set after geometry optimization and calculation of the vibrational frequencies by using the $6-31 \mathrm{G}(\mathrm{d})$ basis set. The solvent influence was treated through the polarized continuum model (PCM) with the default parameters for THF, and the $\mathrm{p} K_{\mathrm{a}}$ values were obtained from the Gibbs energy of the homodesmic reaction between the studied and probe aromatic substrates.

[10] a) H. W. Gschwend, H. R. Rodriguez, Org. React. 1979, 26, 1-360; b) P. Beak, V. Snieckus, Acc. Chem. Res. 1982, 15, 306-312; c) V Snieckus, Chem. Rev. 1990, 90, 879-933; d) T. G. Gant, A. I. Meyers Tetrahedron 1994, 50, 2297-2360; e) M. Schlosser, Organometallics in Synthesis 2002, 2nd ed. (Ed.: M. Schlosser), Wiley: New York, Chapter I.

[11] M. C. Whisler, S. MacNeil, V. Snieckus, P. Beak, Angew. Chem. Int. Ed. 2004, 43, 2206-2225.

[12] P. Beak, G. R. Brubaker, R. F. Farney, J. Am. Chem. Soc. 1976, 98 , 3621-3627.

[13] a) L. Klier, T. Bresser, T. A. Nigst, K. Karaghiosoff, P. Knochel, J. Am Chem. Soc. 2012, 134, 13584-13587; b) L. Klier, D. S. Ziegler, R. Rahimoff, M. Mosrin, P. Knochel, Org. Process Res. Dev. 2017, 21, 660-663.

[14] M. Ehrlich, T. Carell, Eur. J. Org. Chem. 2013, 2013, 77-83.

[15] D. Haas, D. Sustac-Roman, S. Schwarz, P. Knochel, Org. Lett. 2016, $18,6380-6383$

[16] a) S. H. Wunderlich, P. Knochel, Angew. Chem. Int. Ed. 2007, 46 7685-7688; b) M. Mosrin, P. Knochel, Org. Lett. 2009, 11, 1837-1840 c) T. Bresser, M. Mosrin, G. Monzon, P. Knochel, J. Org. Chem. 2010, 75, 4686-4695.

[17] W. Lin, O. Baron, P. Knochel, Org. Lett. 2006, 8, 5673-5676.

[18] K. Snégaroff, J.-M. L'Helgoual'ch, G. Bentabed-Ababsa, T. T. Nguyen, F. Chevallier, M. Yonehara, M. Uchiyama, A. Derdour, F. Mongin, Chem. Eur. J. 2009, 15, 10280-10290.

[19] Z. Zeng, S. C. Zimmerman, Tetrahedron Lett. 1988, 29, 5123-5124.

[20] a) J. M. L'Helgoual'ch, A. Seggio, F. Chevallier, M. Yonehara, E. Jeanneau, M. Uchiyama, F. Mongin, J. Org. Chem. 2008, 73, 177-183 b) P. García-Álvarez, R. E. Mulvey, J. A. Parkinson, Angew. Chem. Int Ed. 2011, 50, 9668-9671.

[21] a) A. Frischmuth, M. Fernández, N. M. Barl, F. Achrainer, H. Zipse, G. Berionni, H. Mayr, K. Karaghiosoff, P. Knochel, Angew. Chem. Int. Ed. 2014, 53, 7928-7932; b) M. R. Becker, P. Knochel, Angew. Chem. Int Ed. 2015, 54, 12501-12505; c) M. R. Becker, M. A. Ganiek, P. Knochel Chem. Sci. 2015, 6, 6649-6653.

[22] R. A. Kjonaas, R. K. Hoffer, J. Org. Chem. 1988, 53, 4133-4135.

[23] a) M. A. Fuentes, A. R. Kennedy, R. E. Mulvey, J. A. Parkinson, T. Rantanen, S. D. Robertson, V. Snieckus, Chem. Eur. J. 2015, 21 14812-14822; b) M. Uzelac, A. R. Kennedy, E. Hevia, R. E. Mulvey, Angew. Chem. Int. Ed. 2016, 55, 13147-13150; c) R. McLellan, M. Uzelac, A. R. Kennedy, E. Hevia, R. E. Mulvey, Angew. Chem. Int. Ed. 2017, 56, 9566-9570.

[24] M. R. Odrowaz-Sypniewski, P. G. Tsoungas, G. Varvounis, P. Cordopatis, Tetrahedron Lett. 2009, 50, 5981-5983.

[25] R. Amara, G. Bentabed-Ababsa, M. Hedidi, J. Khoury, H. Awad, E Nassar, T. Roisnel, V. Dorcet, F. Chevallier, Z. Fajloun, F. Mongin, Synthesis 2017, 49, accepted.

[26] K. Snégaroff, S. Komagawa, F. Chevallier, P. C. Gros, S. Golhen, T. Roisnel, M. Uchiyama, F. Mongin, Chem. Eur. J. 2010, 16, 8191-8201.

[27] P. Beak, S. T. Kerrick, D. J. Gallagher, J. Am. Chem. Soc. 1993, 115 10628-10636

[28] a) F. Chevallier, Y. S. Halauko, C. Pecceu, I. F. Nassar, T. U. Dam, T. Roisnel, V. E. Matulis, O. A. Ivashkevich, F. Mongin, Org. Biomol. Chem. 2011, 9, 4671-4684; b) F. Chevallier, T. Blin, E. Nagaradja, F. Lassagne, T. Roisnel, Y. S. Halauko, V. E. Matulis, O. A. Ivashkevich, F. Mongin, Org. Biomol. Chem. 2012, 10, 4878-4885; c) E. Nagaradja, F. Chevallier, T. Roisnel, V. Dorcet, Y. S. Halauko, O. A. Ivashkevich, V. E. Matulis, F. Mongin, Org. Biomol. Chem. 2014, 1475-1487; d) E. Nagaradja, G. Bentabed-Ababsa, M. Scalabrini, F. Chevallier, S. Philippot, S. Fontanay, R. E. Duval, Y. S. Halauko, O. A. Ivashkevich, V. 
E. Matulis, T. Roisnel, F. Mongin, Bioorg. Med. Chem. 2015, 23 , 6355-6363; e) M. Hedidi, G. Bentabed-Ababsa, A. Derdour, Y. S Halauko, O. A. Ivashkevich, V. E. Matulis, F. Chevallier, T. Roisnel, V. Dorcet, F. Mongin, Tetrahedron 2016, 72, 2196-2205.

[29] Q. Chen, X. Mollat du Jourdin, P. Knochel, J. Am. Chem. Soc. 2013, 135, 4958-4961.

[30] M. Mosrin, G. Monzon, T. Bresser, P. Knochel, Chem. Commun. 2009, 5615-5617.

[31] K. Snégaroff, T. T. Nguyen, N. Marquise, Y. S. Halauko, P. J. Harford, T. Roisnel, V. E. Matulis, O. A. Ivashkevich, F. Chevallier, A. E. H. Wheatley, P. C. Gros, F. Mongin, Chem. Eur. J. 2011, 17 13284-13297.

[32] F. Mongin, Chimia 2016, 70, 48-52.

[33] F. Mongin, M. Schlosser, Tetrahedron Lett. 1997, 38, 1559-1562.

[34] F. Mongin, C. Curty, E. Marzi, F. R. Leroux, M. Schlosser, ARKIVOC 2015, 48-65.

[35] a) E. Negishi, A. O. King, N. Okukado, J. Org. Chem. 1977, 42, 1821-1823; b) E. Negishi, Acc. Chem. Res. 1982, 15, 340-348.

[36] F. Buron, J. Y. Mérour, M. Akssira, G. Guillaumet, S. Routier, Eur. J. Med. Chem. 2015, 95, 76-95.

[37] X. Niu, B. Yang, S. Fang, Y. Li, Z. Zhang, J. Jia, C. Ma, Tetrahedron 2014, 70, 4657-4660.

[38] Y.-C. Teo, F.-F. Yong, S. Sim, Tetrahedron 2013, 69, 7279-7284.

[39] J. C. Antilla, J. M. Baskin, T. E. Barder, S. L. Buchwald, J. Org. Chem. 2004, 69, 5578-5587.

[40] M. Hedidi, W. Erb, G. Bentabed-Ababsa, F. Chevallier, L. Picot, V. Thiery, S. Bach, S. Ruchaud, T. Roisnel, V. Dorcet, F. Mongin, Tetrahedron 2016, 72, 6467-6476.

[41] T. T. Nguyen, N. Marquise, F. Chevallier, F. Mongin, Chem. Eur. J. 2011, 17, 10405-10416.
[42] C. R. Illig, C. L. Manthey, M. J. Wall, S. K. Meegalla, J. Chen, K. J. Wilson, S. K. Ballentine, R. L. DesJarlais, C. Schubert, C. S. Crysler, Y Chen, C. J. Molloy, M. A. Chaikin, R. R. Donatelli, E. Yurkow, Z. Zhou, M. R. Player, B. E. Tomczuk, J. Med. Chem. 2011, 54, 7860-7883.

[43] R. A. Hollins, M. T. L. Lima, J. Heterocycl. Chem. 1979, 16, 679-680.

[44] D. Briel, Pharmazie 1991, 46, 455-456.

[45] D. Horiuchi, R. Camarda, A. Y. Zhou, C. Yau, O. Momcilovic, S. Balakrishnan, A. N. Corella, H. Eyob, K. Kessenbrock, D. A. Lawson, L. A. Marsh, B. N. Anderton, J. Rohrberg, R. Kunder, A. V. Bazarov, P Yaswen, M. T. McManus, H. S. Rugo, Z. Werb, A. Goga, Nat. Med. 2016, 22, 1321-1329.

[46] H. E. Gottlieb, V. Kotlyar, A. Nudelman, J. Org. Chem. 1997, 62 7512-7515

[47] F. Trécourt, F. Marsais, T. Güngor, G. Queguiner, J. Chem. Soc. Perkin Trans. 1 1990, 2409-2415.

[48] K. Kobayashi, T. Komatsu, K. Nakagawa, E. Hara, S. Yuba, Heterocycles 2013, 87, 2577-2587.

[49] N. Marquise, P. J. Harford, F. Chevallier, T. Roisnel, V. Dorcet, A.-L. Gagez, S. Sablé, L. Picot, V. Thiéry, A. E. H. Wheatley, P. C. Gros, F. Mongin, Tetrahedron 2013, 69, 10123-10133.

[50] R. A. Hollins, V. M. Salim, Tetrahedron Lett. 1979, 591-592.

[51] D. Tilly, S. S. Samanta, A.-S. Castanet, A. De, J. Mortier, Eur. J. Org. Chem. 2006, 174-182.

[52] C. F. Koelsch, J. Am. Chem. Soc. 1932, 54, 4744-4749.

[53] N. Marquise, F. Chevallier, E. Nassar, M. Frédérich, A. Ledoux, Y. S. Halauko, O. A. Ivashkevich, V. E. Matulis, T. Roisnel, V. Dorcet, F Mongin, Tetrahedron 2016, 72, 825-836.

[54] A. Krasovskiy, V. Malakhov, A. Gavryushin, P. Knochel, Angew. Chem. Int. Ed. 2006, 45, 6040-6044. 
Key topic: Ketone functionalization

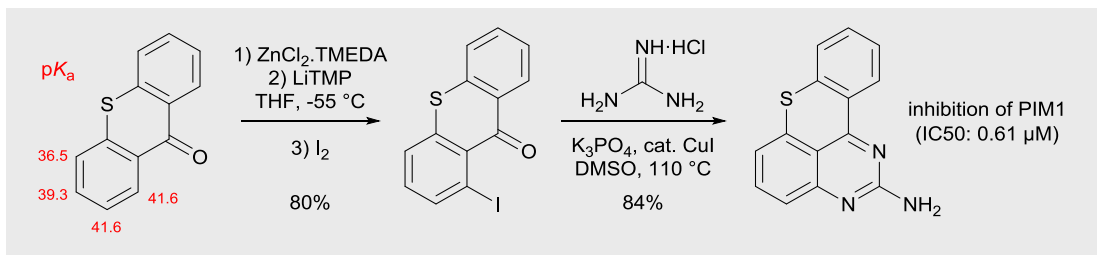

Aromatic ketones were functionalized by deprotolithiation in the presence of a zinc salt followed by iodolysis. The outcome of the reactions was analyzed in the light of the calculated $p K_{\mathrm{a}}$ values. The iodo derivatives were involved in copper-catalyzed two-fold $\mathrm{C}-\mathrm{N}$ bond formation to afford fused systems based on 2-aminopyrimidines. Besides potential antibacterial effect, 2-aminobenzothiopyrano[4,3,2-de]quinazoline proved to inhibit PIM1 $\left(\mathrm{IC}_{50}: 0.61 \mu \mathrm{M}\right)$ and CDK2/cyclin $\mathrm{A}\left(\mathrm{IC}_{50}: 2.0 \mu \mathrm{M}\right)$ kinases.
M. Hedidi, J. Maillard, W. Erb, F. Lassagne, Y. S. Halauko, * O. A. Ivashkevich, V. E. Matulis, T. Roisnel, V. Dorcet, M. Hamzé, Z. Fajloun, ${ }^{*} B$. Baratte, S. Ruchaud, S. Bach, * G. Bentabed-Ababsa* and F. Mongin*

Fused systems based on 2aminopyrimidines: synthesis combining deprotolithiation-in situ zincation with $\mathrm{N}$-arylation reactions and biological properties 